\title{
A Survey of Matrix Materials for Solidified Radioactive High-Level Waste
}

W. E. Gurwell

September 1981

Prepared for the U.S. Department of Energy under Contract DE-AC06-76RLO 1830

Pacific Northwest Laboratory Operated for the U.S. Department of Energy by Battelle Memorial Institute 


\title{
NOTICE
}

This report was prepared as an account of work sponsored by the United States Government. Neither the United States nor the Department of Energy, nor any of their employees, nor any of their contractors. subcontractors, or their employees, makes any warranty, express or implied, or assumes any legal liability or responsibility for the accuracy. completeness or usefulness of any information, apparatus, product or process disclosed, or represents that its use would not infringe privately owned rights.

The views. opinions and conclusions contained in this report are those of the contractor and do not necessarily represent those of the United States Government or the United States Department of Energy.

\author{
PACIFIC NORTHWEST LABORATORY \\ operated by \\ BATTELLE \\ for the \\ UNITED STATES DEPARTMENT OF ENERGY \\ Under Contract DE-AC06-76RLO 1830
}

\author{
Printed in the United States of America \\ Available from \\ National Technical Information Service \\ United States Department of Commerce \\ 5285 Port Royal Road \\ Springfield. Virginia 22151
}

Price: Printed Copy $\mathbf{s}$

$\because$ Microfiche $\$ 3.00$

NTIS

-Pages Selling Price

$001.025 \quad \$ 4.00$

$026.050 \quad 54.50$

$051.075 \quad \$ 5.25$

076-100 $\$ 6.00$

$101-125 \quad \$ 6.50$

126-150 \$7. 25

$151-175 \quad \$ 8.00$

$176-200 \quad 59.00$

$201-225 \quad 59.25$

226-250 $\$ 9.50$

$251-275 \quad \$ 10.75$

$276-300 \quad \$ 11.00$ 


\section{0}

\section{A SURVEY OF MATRIX MATERIALS FOR SOL IDIFIED RADIOACTIVE HIGH-LEVEL WASTE}

W. E. Gurwe11

September 1981

Prepared for the U.S. Department of Energy under Contract DE-AC06-76RLO 1830

Pacific Northwest Laboratory Richland, WA 99352 


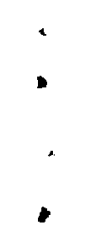




\section{SUMMARY}

Pacific Northwest Laboratory (PNL) has been investigating advanced waste forms, including matrix waste forms, that may provide a very high degree of stability under the most severe repository conditions. The purpose of this study was to recommend practical matrix materials for future development that most enhance the stability of the matrix waste forms.

The functions of the matrix were reviewed. Desirable matrix material properties were discussed and listed relative to the matrix functions. Potential matrix materials were discussed and recommendations were made for future matrix development.

The matrix mechanically contains waste cores, reduces waste form temperatures, and is capable of providing a high-quality barrier to leach waters. High-quality barrier matrices that separate and individually encapsulate the waste cores are fabricated by powder fabrication methods, such as sintering, hot pressing, and hot isostatic pressing. Viable barrier materials are impermeable, extremely corrosion resistant, and mechanically strong. Three material classes potentially satisfy the requirements for a barrier matrix and are recommended for development: titanium, glass, and graphite. Polymers appear to be marginally adequate, and a more thorough engineering assessment of their potential should be made. 
CONTENTS

SUMMARY

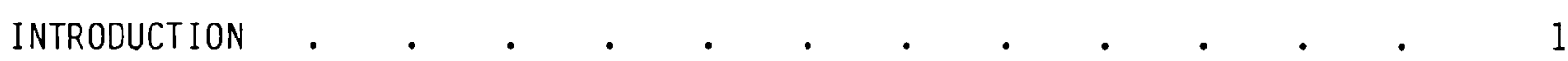

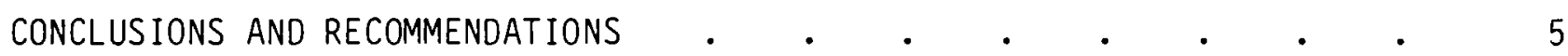

DESIRABLE MATRIX MATERIAL CHARACTERISTICS $\quad . \quad$. $\quad . \quad$. $\quad$. $\quad$. 7

CORROSION RESISTANCE $\quad$.

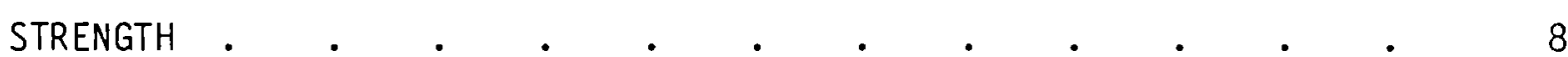

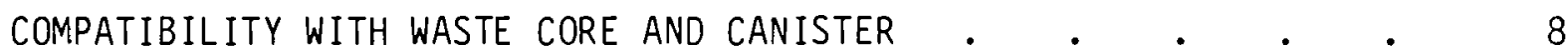

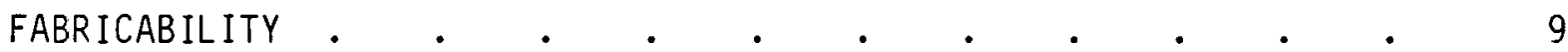

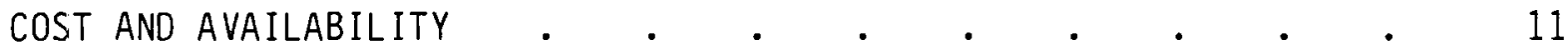

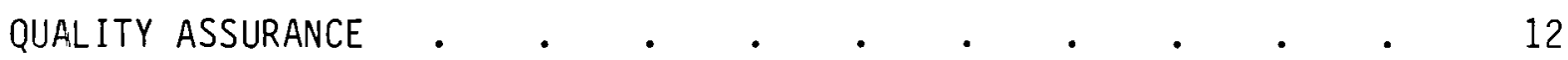

SAFETY AND TOXICITY .

SUMMARY OF DESIRABLE CHARACTERISTICS

MATRIX MATERIAL SELECTION

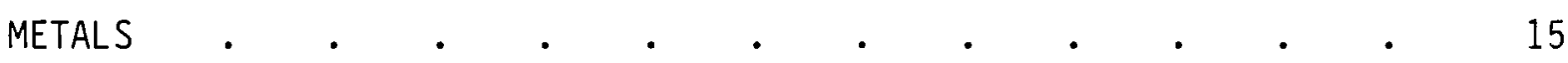

Titanium .

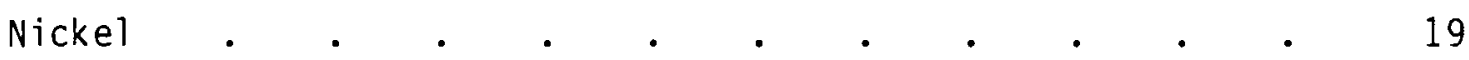

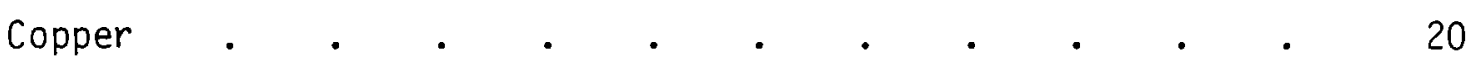

Stainless Steel $. \quad . \quad . \quad . \quad . \quad . \quad . \quad . \quad . \quad 21$

Lead . . . . . . . . . . . . 22

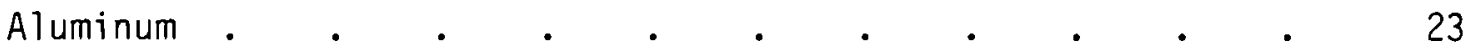

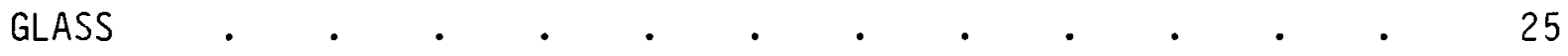

POLYMERS . . . . . . . . . . . . . . . . . . 27

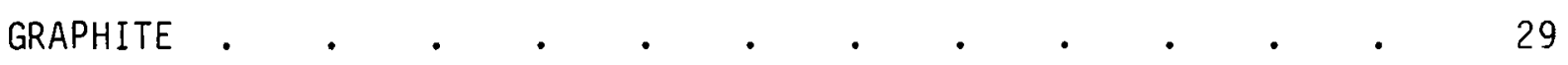

CERAMICS . . . . . . . . . . . . . . 30 


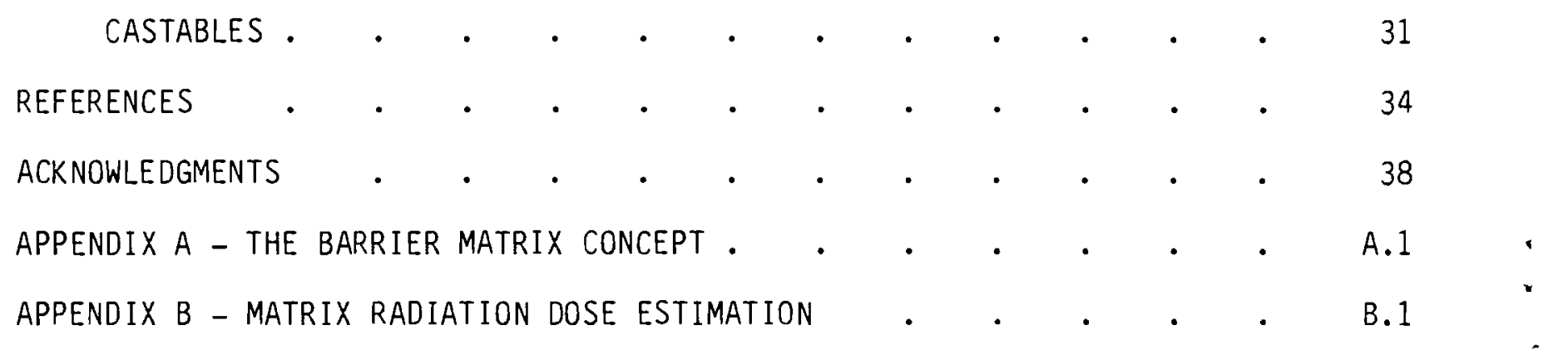




\section{FIGURES}

1 Matrix and Monolithic Waste Forms . $\quad$. $\quad . \quad$. $\quad$. $\quad 2$

A.1 Idealized Barrier Matrix Waste Form $\quad$. . . . . . . . A.2

A.2 Geometric Relationships at Constant Waste Core Mass . . . A.5

B.1 Gamma Dose-to-Matrix as a Function of Matrix Density . . . B. 6

\section{TABLES}

1 Advantages and Disadvantages of Matrix Waste Forms . . . $\quad 3$

2 Representative Waste Core Properties . . . . . . . 10

3 Representative Corrosion Rates . . . . . . . . . . . 16

4 Representative Metal Matrix Properties . . . . . . . 17

5 Representative Nonmetal Matrix Properties . . . . . . 26

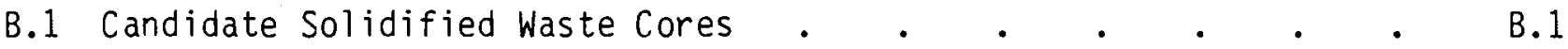

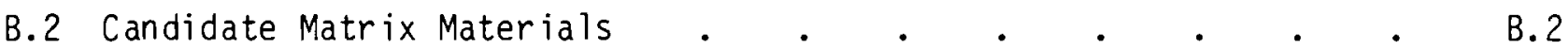

B.3 Accumulated Gamma Dose as a Function of Time . . . . . . B.4

B.4 Alpha Doses and Dose Rates . . . . . . . . . . . . . B.5

B.5 Gamma Dose Rate to Matrix Material as a Function of Waste Age 
• 


\section{INTRODUCTION}

Nuclear waste can be solidified by numerous processes. During the $1960 \mathrm{~s}$ the Atomic Energy Commission conducted small-scale research and development (R\&D) projects on a variety of alternate consolidation processes. As a result of this work and later studies in the United States and in other countries, monolithic glass was chosen as a reference form due primarily to its simplicity in processing, its ability to accommodate a broad-range of waste compositions, and the fact that the properties of the resultant product adequately met the design criteria for repositories. Recently, however, a renewed interest in advanced waste forms has developed because potential repository conditions may be more severe with respect to temperature, pressure, and aqueous media than originally anticipated. Pacific Northwest Laboratory $(\mathrm{PNL})^{(a)}$ is responding to this concern by investigating advanced waste forms that may provide a very high degree of stability under the most severe repository conditions.

Waste forms may be either a simple monolith or a group of waste cores (pellets or marbles) contained within a matrix material (known as the matrix waste form). Both forms are illustrated in Figure 1, and advantages and disadvantages of the matrix waste form are listed in Table 1.

To date, matrix materials have been primarily developed to contain the waste pellets or marbles mechanically and to reduce waste temperatures in high heat load wastes, e.g., young commercial wastes. Lead and aluminum matrices could perform these functions well. Defense wastes and old commercial wastes (a large inventory of spent unreprocessed fuel currently exists) have relatively low heat content. There is also a great deal of interest in the development of a long-lived engineered barrier system for nuclear waste containment. These facts shift the emphas is from high thermal conductivity matrix materials and suggest that more consideration ought to be given to the barrier properties of the matrix material. This approach requires consideration of a variety of matrix materials such as ceramics, carbons, metals, and perhaps even polymers.

(a) Operated for the U.S. Department of Energy (DOE) by Battelle Memorial Institute. 


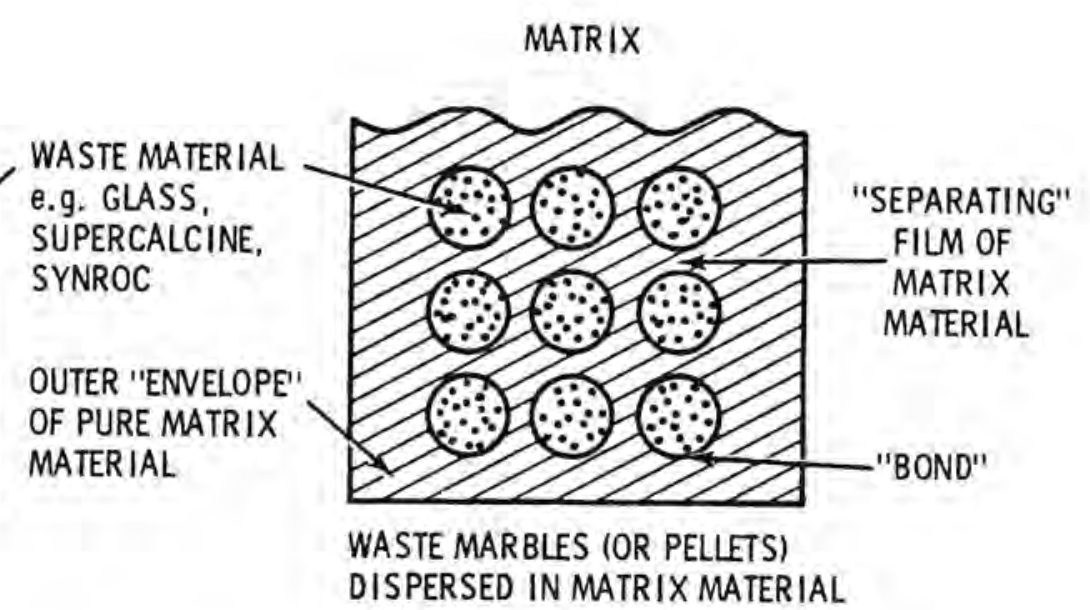

FIGURE 1. Matrix and Monolithic Waste Forms

The barrier matrix waste form concept has the attractive features of a truly redundant, long-lived engineered barrier system for nuclear waste containment. A matrix waste form could possibly eliminate the need for other engineered barriers, such as an overpack or a hole sleeve. Proposed U.S. Nuclear Regulatory Commission (NRC) regulations (10 CFR 60) require near-zero release from the waste package for $1000 \mathrm{yr}$ and $10^{-5} / \mathrm{yr}$ radionuclide release rates thereafter.

If properly designed, the outer waste-free envelope of pure matrix material (see Figure 1) would shield the waste from leach waters for $1000 \mathrm{yr}$, thus providing zero release of radionuclides during that period. After the envelope is penetrated, the matrix would be expected to decrease the leach rate of the waste cores to assure that release rates remain below $10^{-5} / \mathrm{yr}$.

Two features of the matrix contribute toward maintaining $10^{-5} / \mathrm{yr}$ release rates after 1000 yr (see Figure 1):

- a separating film of matrix material between the waste cores that encapsulates (or coats) and protects the individual waste cores (e.g., marbles)

- a bond between the matrix and waste core that limits the waste core area exposed to leach waters. 
TABLE 1. Advantages and Disadvantages of Matrix Waste Forms Advantages of Matrix Waste Forms

- Pellets or marbles are amenable to quality assurance testing, resistant to thermal stress cracking, and inherently have more uniform microstructures than large monoliths. In addition, they can be coated with additional barrier materials if desired.

- The matrix has the following barrier properties:

- The outer protective envelope of matrix material can delay the initiation of waste leaching.

- Once the envelope is penetrated, the matrix can lower the rate of waste leaching.

- A matrix crack constitutes partial failure; on the other hand, a crack in the can or overpack would expose all the waste in a monolith. The matrix is more compact and solid; therefore, brittle materials are more acceptable in matrices than in cans or overpacks.

- A matrix waste form can reduce waste dispersal during transportation accidents and during retrieval of corroded waste canisters.

- Dilution of the waste with matrix material will generally reduce waste temperatures and, therefore, improve the microstructural stability and leach resistance of the waste. A high thermal conductivity matrix is particularly advantageous for fresh commercial wastes.

Disadvantages of Matrix Waste Forms

- added process complexity

- increased canister size (with constant waste loading per canister).

Either of the features--the bond or the separating film--will prevent "wicking" or water penetration throughout the entire waste form via unbonded channels between the matrix and waste core. The conventional cast lead matrix suffers from wicking because it contains neither a bond nor a separating film, 
and wicking results in leach rates that are no better than those for the glass alone (Alternative Waste Form Peer Review Panel 1981, p. 15). The matrix does not function as a high-quality barrier unless either one or both of the features is present. In general, the separating film itself is a good guarantee against wicking if 1 ) bonding does not occur in some waste core matrix combinations, 2) bond layers fail under thermal and mechanical loading, and 3) some compounds present in the bond layer have poor resistance to corrosion and/or radiation (combined alpha and gamma). The separating film also provides a more robust matrix that is better able to resist cracking due to thermal and mechanical stresses. Finally, separating films of highly corrosion-resistant matrix materials could substantially reduce release rates. The barrier matrix concept is discussed in more detail in Appendix A.

The following section of this report discusses desirable material characteristics for a barrier matrix. Candidate matrix materials are then described, and recommendations are made for future matrix material development. 


\section{CONCLUSIONS AND RECOMMENDATIONS}

Matrix waste forms have been developed to contain waste pellets or marbles mechanically and to reduce waste temperatures in high heat load wastes. The matrix waste form can also be considered to comprise two essentially redundant barriers to leach waters: a stable, leach-resistant matrix (including an outer protective envelope) and a stable, leach-resistant waste core. This conservative waste form design is a promising answer to the requirement of zero release from the waste package for $1000 \mathrm{yr}$ and $10^{-5} / \mathrm{yr}$ release thereafter as described in the draft NRC regulation 10 CFR 60. Viable matrix materials would be impermeable, extremely corrosion resistant, and mechanically strong.

The barrier matrix reaches its highest potential when a separating film of matrix material is present to encapsulate individual waste cores. The separating film eliminates wicking, strengthens the matrix against cracking, reduces waste temperatures, and can substantially reduce radionuclide release rates in cases where the matrix material corrodes slower than the waste core. Separating films can be obtained in matrices fabricated by powder methods such as sintering, hot pressing, or hot isostatic pressing (HIP).

Several material classes potentially satisfy the requirements for a barrier matrix:

- Several metals are potential matrix materials. Titanium has an unusually high corrosion resistance over a broad range of temperatures and environments, and the development of a titanium matrix should receive major emphasis. Other metals such as nickel, copper, and stainless steel are more limited but may be viable in specific repository environments that may be identified in the future. While lead and aluminum matrices reduce waste temperatures, their corrosion resistance is marginal at low temperatures and poor at higher temperatures; hence, their potential as barrier matrices is low.

- Glass matrices with a wide variety of properties can be fabricated by powder glass fabrication processes to full density at moderate temperatures. Their corrosion resistance will be roughly equivalent 
to that of the waste core; hence, the main barrier value of a glass matrix is its envelope, which may be sufficient for highly corrosionresistant waste cores. The development of glass matrix materials should be pursued.

- Graphite reacts extremely slowly with water; thus, its potential as a barrier is tremendous. Graphite powders can be compacted to highdensity shapes at low temperatures having strengths of -1500 psi. Unfortunately, these powder compacts are permeable to water as are graphite shapes that are conventionally processed at high temperatures $\left(2200^{\circ} \mathrm{C}\right)$. The development of impermeable graphite matrices should be pursued using the compacted graphite powder approach. Compatible methods of sealing or filling residual porosity need to be developed.

- Polymers are generally stable in aqueous solutions, potentially inexpensive, and may be fabricated by a variety of low-temperature processes. However, polymers are sensitive to radiation and elevated temperatures but appear to be marginally capable of remaining stable in the waste form environment (application may be limited to lower level wastes, such as defense wastes). The potential of polymer matrices should be evaluated through an engineering assessment of the stability of polymer matrices and methods of ameliorating the problems. 


\section{DESIRABLE MATRIX MATERIAL CHARACTERISTICS}

Useful matrix materials will have certain characteristics that will be determined by the overall waste treatment and storage system. Due to the broad spectrum of possible high-level waste (HLW) disposal systems and to a general lack of data (e.g., long-term corrosion behaviors and repository environments), the desirable matrix materials can only be defined broadly. In the following seven sections desirable characteristics are discussed with respect to:

- corrosion resistance

- strength

- compatibility with waste core and canister

- fabricability

- cost and availability

- quality assurance

- safety and toxicity.

\section{CORROSION RESISTANCE}

Corrosion resistance is the prime quality of a highly effective barrier matrix, but it is difficult to evaluate because exact repository conditions are not defined and the possible range of repository conditions is broad. In addition, corrosion data are not available for the long time periods pertinent to geologic disposal of HLW. Even relative corrosion rates between materials are poorly known and environment specific. The situation is further complicated by marked differences in corrosion behaviors in various solutions and temperatures (Mendel et al. 1981, pp. 4.41-4.46; Fullam 1980, pp. 57-62).

At this time, matrix material selection will have to be based on best engineering judgment. Generic materials (e.g., copper) representative of a class of materials (e.g., copper alloys) will be picked for subsequent demonstration of feasibility. In the future, system designers will make the final choice based upon the generic matrices developed related to the system requirements. Composition refinement (selection of particular alloys) for optimization would logically be done after the generic matrix feasibility is 
demonstratedand the system is defined. (The final design may incorporate buffer materials in the backfill to reduce corrosion in selected materials.)

In order for a 1-cm thick envelope to provide a 1000-yr barrier, a matrix material corrosion rate of less than $0.001 \mathrm{~cm} / \mathrm{yr}$ is required. (At that rate a $0.2-\mathrm{cm}$ thick separating film of matrix material between the waste cores will delay the spread of leach solution to the next layer for $200 \mathrm{yr}$.) The possible range of conditions covers brines and ground water, oxygenated or deoxygenated, and temperatures of 25 to $250^{\circ} \mathrm{C}$.

Long-term corrosion resistance of the matrix must not be impaired by the effects of radiation from the waste core. The expected major effects on the bulk matrix are due to gamma radiation. The maximum estimated gamma dose to a

matrix containing HLW cores is $2 \times 10^{11}$ rads in $1000 \mathrm{yr}$; the maximum alpha dose is estimated to be $2 \times 10^{7}$ rads in a thin ( 15-um thick) layer (see Appendix $B)$. Polymeric materials will degrade by cross linking and chain scission (Westerman et al. 1979); and hydraulic setting cements (e.g., castables) will degrade by radiolytic decomposition of water (Bibler 1978). Although definitive data concerning radiation stability are lacking for most other matrix materials including metals (Jardine and Steindler 1978, p. 26), no major radiation stability problems have been anticipated for those materials.

\section{STRENGTH}

The waste must be immobilized during shipping and repository handling. Although the canister and shipping cask fulfill this function for the most part (slate et al. 1978), a strong matrix will enhance immobilization. No real strength criteria are available; ideally, a barrier matrix would be crack free. All other things being equal, stronger materials will resist cracking better and ductile materials have a distinct advantage over brittle materials in limiting cracking. Thus, metals would generally be favored in assessing strength characteristics.

\section{COMPATIBILITY WITH WASTE CORE AND CANISTER}

Ideally, there should be potential for a strong compliant bond between the waste core and the matrix. Undesirable reactions such as eutectic melting 
between the matrix and either the canister or waste core are to be avoided. The matrix must be fabricable at temperatures that neither degrade the waste cores nor cause gross contamination of the matrix with volatile fission products from the waste core. A thermal expansion mismatch between the waste core and matrix needs to be minimized, especially with brittle matrices. Some waste core properties pertinent to compatibility are listed in Table 2.

\section{FABR ICABIL ITY}

The matrix must be fabricable to a water impermeable (high-density) structure at temperatures compatible with the waste core, and process simplicity is important for hot cell fabrication.

Fabrication procedures should be developed to provide a separating membrane of matrix material between the waste cores. Possible methods of achieving waste core separation are: 1) mechanically placing the waste cores and matrix powder; 2) coating the waste cores with matrix material; and 3) simple mixing of the waste cores and powder matrix material (like mixing concrete) followed by pressing or casting. The third method does not guarantee that the cores are not touching, but on the average they will be separated by a web thickness determined by the waste core diameter and the volume percent (vol\%) of cores in the mix. Powder consolidation methods that can be used to achieve high density include hot pressing, HIP, and forging. Thixocasting is a potential method of attaining waste core separation in cast metal matrices (Neumann 1979).

Quite often corrosion-resisting properties of materials are sensitive to fabrication history due to microstructural differences that may develop (phase changes, segregation, impurities, etc.). For this reason, corrosion data must be carefully obtained and used. New corrosion data should be developed specifically for the fabrication processes used and the repository environments contemplated. 


\section{TABLE 2. Representative Waste Core Properties(a)}

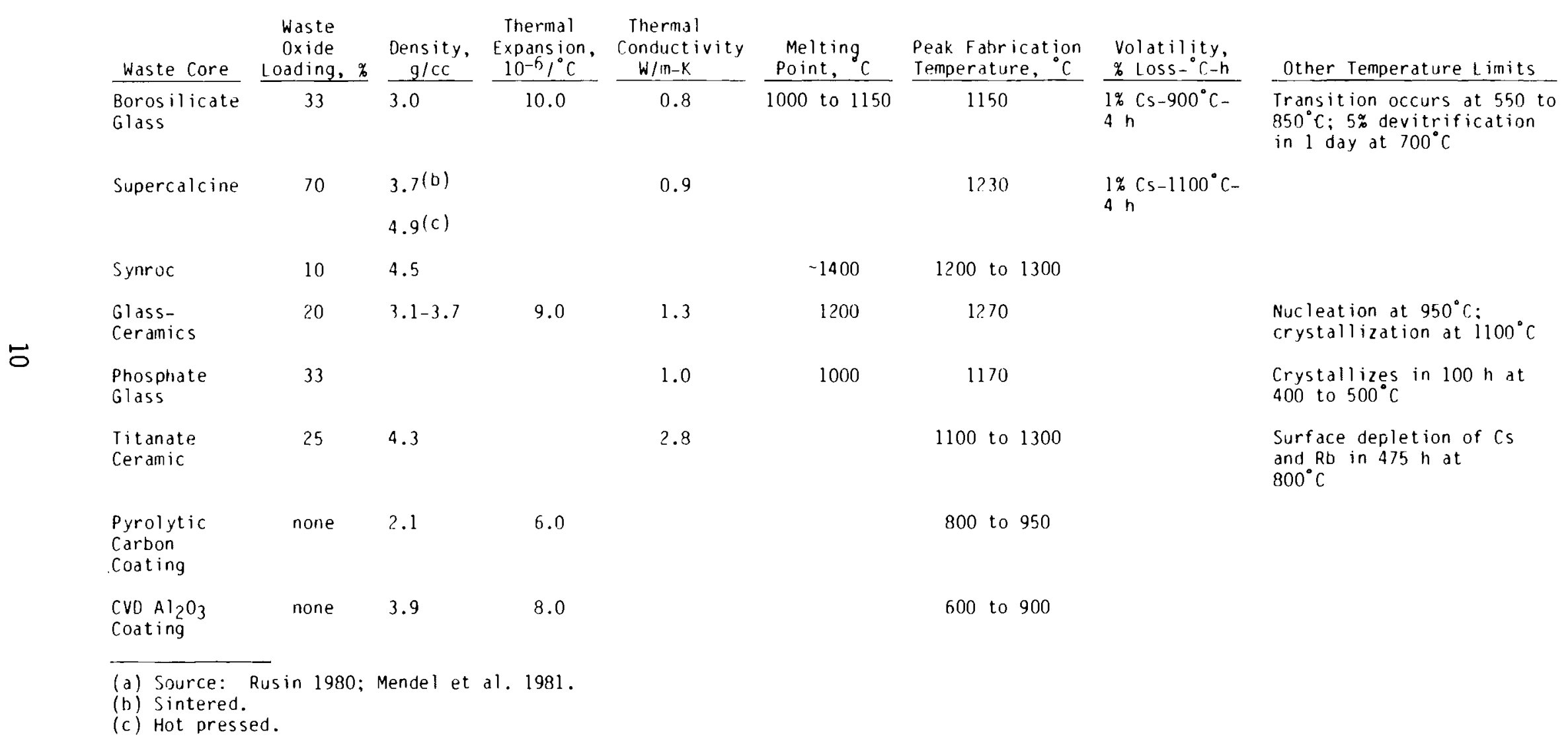




\section{COST AND AVAILABILITY}

Ultimately, the systems designer will select a matrix material by optimizing benefits relative to matrix cost. Although systems design is beyond the scope of this study, matrix costs can be put in perspective by determining the cost impact of the matrix on the price of electricity to the consumer. The ratio of matrix material cost to electricity price $\left(10^{-6} \rho p \%\right)$ is based upon the following assumptions:

- 40 vol\% matrix of density $\rho=\mathrm{g} / \mathrm{cm}^{3}$, and price $\mathrm{p}=\$ / \mathrm{Mg}$ (watts et al. 1980)

- $100 \mathrm{~kg}$ of waste oxide per MgU (megagram or metric ton uranium) (Ross et al. 1978)

- $33 \%$ waste oxide loading in the waste core

- $3 \mathrm{~g} / \mathrm{cc}$ waste core density

- 10,000 MWd of electricity generated per MgU at a consumer cost of $5 \$ / \mathrm{kWh}$; transmission 1 oss $=17 \%$.

In the following matrix material selection, those materials costing more than $0.1 \%$ of the electricity value are arbitrarily deemed to be too costly.

Availability of materials can be affected by many factors (Watts et al. 1980) including production capacity, reserves, distance to source of supply, politics, processing technology, and concentration of ore. Since materials buried with the nuclear waste will be unavailable for reuse for nearly $1000 \mathrm{yr}$, future generations may possibly be denied access to needed materials. Although detailed study of material availability is beyond the scope of this study, such study should be carried out as the materials requirements for waste disposal are defined.

A simple, key measure of material availability for HLW disposal will be obtained by comparing HLW disposal requirements to U.S. consumption of the material for a single year. The projected amount of light water reactor (LWR) fuel to be reprocessed in the year 2000 is $14,000 \mathrm{MgU}$ (U.S. ERDA 1976, 
p. 310). Although recent lowered projections of nuclear capacity (Park and Yates 1979) indicate that the amount of fuel to be reprocessed will be substantially less, the 14,000-MgU value will be used for conservatism. Assuming that all the waste from the $14,000 \mathrm{MgU}$ is converted to the matrix waste form along with the previous assumptions, the amount of a material used in matrix waste forms relative to the total U.S. consumption of the material in the year 2000 is calculated by the simple formula:

$$
1.4 \times 10^{5} \% / c \%
$$

where $c$ is the projected U.S. consumption of the material in the year 2000 in $\mathrm{Mg}$ and $\rho$ is the matrix density in $\mathrm{g} / \mathrm{cm}^{3}$. U.S. consumption for each material was taken from the data base of watts et al. (1980), which is generally based upon projections made by the U.S. Bureau of Mines (1975). Where Bureau of Mines data were not available, projections were made based on projected growth rates of similar material industries.

When the use of matrix material in HLW immobilization exceeds $1 \%$ of U.S. consumption, availability comes into question. In addition, a surge in usage of the material in HLW could lead to precipitous price increases. In the following matrix material selection, a material is arbitrarily deemed to be safely available for matrix use if the use of the material in HLW matrix waste forms is less than $1 \%$ of the U.S. consumption.

\section{QUALITY ASSURANCE}

Simple means must be available to measure the density and distribution of the matrix. In general, this could be done by measuring weight and/or volume of the waste cores and matrix material before combining them and after fabrication. Some fabrication procedures may require special consideration. Testing will be conducted outside of hot cells for quality assurance of input matrix materials and for process control. 
SAFETY AND TOXICITY

The matrix should not pose a fire hazard or emit noxious substances during fabrication, shipping, or storage. For example, finely divided metal powders can be pyrophoric.

\section{SUMMARY OF DESIRABLE CHARACTERISTICS}

If properly designed, the matrix waste form should be mechanically stable and thermally conductive. It should also provide a long delay from the time that the waste package is first contacted by the repository ground water until the initiation of waste leaching. After the outer waste-free region of the waste form is penetrated, the matrix would be expected to provide a substantial decrease in the leach rate over what would be expected from unprotected waste cores (pellets or marbles). The characteristics listed below reflect a strong emphasis on barrier properties; and they form the bases for matrix material selection, development, and evaluation.

- The matrix system will act as a long-lived barrier to waste leaching. The outer waste-free protective envelope will be sufficiently corrosion resistant to provide zero release for approximately $1000 \mathrm{yr}$. If the outer protective envelope is penetrated, the matrix will protect the waste cores and permit only leach rates much lower than those expected from unprotected waste cores. To accomplish this, a matrix corrosion rate of less than $1 \mathrm{~cm} / 1000 \mathrm{yr}$ is desirable.

- The matrix will retain the particles of waste under anticipated transportation and handling accidents. To accomplish this, the matrix must be strong and impact resistant; and a good waste coreto-matrix bond is desirable.

- The matrix will be chemically, thermally, and mechanically compatible with the waste core and canister.

- The matrix will not impose difficult processing requirements.

- The matrix will not impose high cost or extreme material availability requirements. For the purpose of this survey, 
potential matrix materials arbitrarily cost less than $0.1 \%$ of the value of electricity generated and use less than $1 \%$ of the U.S. consumption in the year 2000 .

- The matrix will be amenable to standard quality assurance inspection procedures.

- The matrix will not by itself impose safety or toxicity problems on the waste disposal concept. 


\section{MATRIX MATERIAL SELECTION}

The following potential matrix material classes--metals, glass, polymers, graphite, ceramics, and castables--were considered. Specific recommendations are made for each material class.

METALS

The major advantage of metals is their ductility, which is beneficial to both toughness (crack resistance) and ease of fabrication by mechanical working at high rates and low temperatures. Metals also have high thermal conductivity. The data in Table 3 indicate that with proper design some metals may function as high-quality barrier matrices in selected environments.

The generic metals listed in Table 3 are plausible matrix materials. The corrosion data given are for alloys that are reasonable choices based solely upon a small amount of corrosion data. The metals portion of the list was distilled from a survey of the Metals Handbook (American Society for Metals 1961 , 1978, and 1979) for all common alloys and all pure metals. Specific metals were eliminated because of poor corrosion resistance, high cost (e.g., precious metals), poor availability (e.g., rare earths), or inability to fabricate at temperatures compatible with waste cores, that is, below $1300^{\circ} \mathrm{C}$ (e.g., refractory metals). Zirconium is an exception and is a logical alternative to titanium because it has very similar corrosion (Braithwaite and Molecke 1978; Shannon 1977) and fabrication characteristics (Schwope 1961). However, titanium is generally more available and seems to be a somewhat better choice for corrosion resistance. Demonstration of titanium will show possibie zirconium feasibility.

Of the metals listed, titanium has an unusually high corrosion resistance over a broad range of environments. For this reason titanium should be the leading metal matrix candidate. Selected nickel-base alloys are close behind followed by stainless steel, copper alloys, lead, and aluminum. Some significant properties of the candidate metal matrix materials are shown in Table 4. 
TABLE 3. Representative Corrosion Rates

Material

Titanium

Ti-Grade 12

Commercially Pure

Nickel

Haste 1 loy C-276

Inconel 600

0.15 to $20(a, c)$

0.5 to 10.0

Copper

Copper

90-10 Cupronicke 1

Stainless Steel $20 \mathrm{Cb} 3$

$316 \mathrm{~L}$

Lead

Aluminum

$1100,3003,3004 \quad \begin{aligned} & \text { Disintegrates in } \\ & \text { a few days }\end{aligned}$ < $\quad<0.7(\mathrm{pH} 4$ to 8.5$)$

$\times 8001$

Good resistance (d)

$0.6(h)$

$1.3^{(h)}$

$\mathrm{TiO}_{2}$

$\mathrm{Al}_{2} \mathrm{O}_{3}$

$\mathrm{ZrO}_{2}$

Graphite

Borosilicate

Waste Glass

Nil to 0.0004 (b) $<0.3(i)$

$$
\begin{aligned}
& \text { Unattacked to } \\
& \text { moderatel } y \text { (d) } \\
& \text { resistant }
\end{aligned}
$$

$<5.0(\mathrm{e})$

$<2.5$

Nil to $0.5^{(d)}$

0.05 to 13.5 (e)

$<0.07(\mathrm{i})$

$<0.7^{(i)}$

$.5(h)$

$<0.07(i, j)$

$70.0^{(f)}$

0.01 to $1.0(\mathrm{~g})$ $1.5(h, j)$

\section{Corrosion Rates, $\mathrm{cm} / 1000 \mathrm{yr}$}

$25^{\circ} \mathrm{C}$ in Marine and

Industrial Atm., Sea

Water, Ground Water $25^{\circ} \mathrm{C}$ Salt Solutions

$<2.5$ general $1 y$; (d)

up to 50.0 in acjd

salt solutions $(d)$

0.25 to 150.0 (e)

(nonoxidizing salts)

(a) Braithwaite and Molecke 1978.

(b) Stough 1957.

(c) Pitting and/or crevice corrosion in oxygenated solutions.

(d) American Society for Metals 1961.

(e) American Society for Metals 1979.

(f) Mendel et al. 1981.

(g) Jardine and Steindler 1978.

(h) Fullam 1980.

(i) Fullam 1980; values given are at $90^{\circ} \mathrm{C}$. Corrosion rates at $25^{\circ} \mathrm{C}$ will be lower.

(j) Based on geometric surface area of samples. If the total permeable surface area is used, leach rates are 2000 to 3000 times lower. 
TABLE 4. Representative Metal Matrix Properties

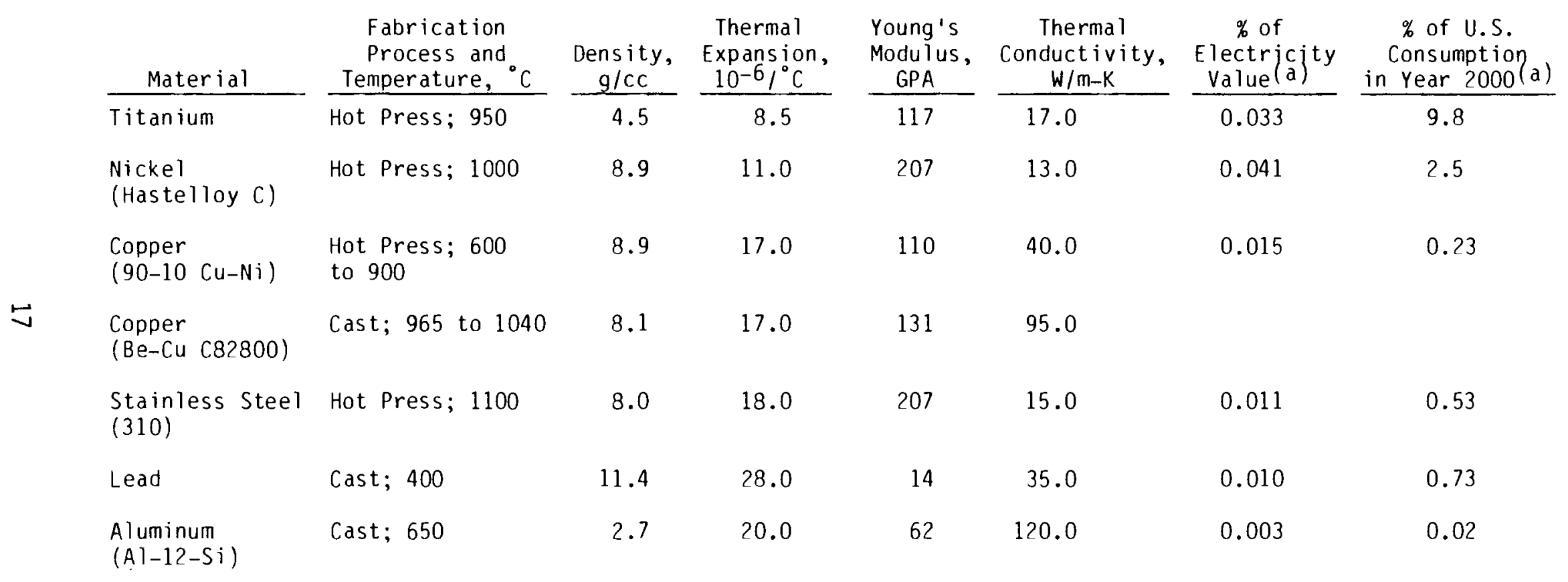

(a) Calculation of these values is discussed on page 11 . 
Titanium

Titanium has excellent resistance to general corrosion and to pitting attack by most salt solutions. Reagents that do corrode titanium are hydrofluoric, hydrochloric, sulfuric, oxalic, and formic acids. In all but hydrofluoric acid the attack can be inhibited by suitable additions. Titanium is normally resistant to sea water, ferric and cupric chloride, nitric acid, chromic acid, and acetic acid. Titanium has good resistance to crevice corrosion (except some acids), cavitation, erosion, corrosion fatigue, and galvanic attack. In galvanic couples it often accelerates the corrosion of the other metal in the couple (Stough 1957). Unalloyed titanium is not susceptible to stress corrosion cracking (SCC) (Jackson and Boyd 1970) except in red fuming nitric acid. The corrosion resistance of titanium results from a complex surface passivation process. In general, titanium tends to passivate in those media that are not strong reducing agents.

Unalloyed titanium has a tensile strength of $300 \mathrm{MPa}(45,000$ psi) and an elongation of $50 \%$.

Titanium will tend to form a thin surface layer of $\mathrm{TiO}_{2}$ that will likely react with the waste core at fabrication temperatures to form complex and stable oxide ceramic phases. High-density titanium matrices can be formed by hot pressing or HIP of titanium powders at $950^{\circ} \mathrm{C}$. Titanium alloy powders have been hot pressed to over 99\% of theoretical density (TD) in $5 \mathrm{~s}$ at pressures of 150 to $200 \mathrm{ksi}$ and temperatures of 800 to $1000^{\circ} \mathrm{C}$ (Friedman and Kazaroff 1971). Crystalline and high-temperature glass waste cores are compatible; however, low-viscosity glass waste cores such as TDS-211 and 76-68 will tend to infiltrate the porous titanium powder. The coefficient of thermal expansion of titanium $\left(8.5 \times 10^{-6},{ }^{\circ} \mathrm{C}\right)$ should provide a good match with most waste cores.

A titanium matrix will cost only $0.03 \%$ of the value of electricity generated (Table 4). A maximum of $10 \%$ of the U.S. consumption of titanium in the year 2000 would be used in titanium matrix HLW forms. Titanium producers would probably welcome a steady customer to dampen the fluctuations in purchases by aircraft manufacturers. Although the titanium ore, rutile, is 
currently imported from Australia, synthetic rutile can be manufactured at a small additional cost from plentiful domestic and foreign ilmenite ores.

There can be a considerable fire and explosion hazard in the handling of large quantities of titanium powder as there is with any finely divided combustible material. The lowest ignition temperature for a titanium dust cloud was measured at $300^{\circ} \mathrm{C}$ (Peterseim 1957). Although titanium powders are now routinely handled, some consideration needs to be given to the effect of the hot waste core on titanium powder combustibility. Presumably, el imination of powder fines, good housekeeping, and minimal contact with the air would be among the appropriate safety precautions.

Nickel

Nickel-base alloys, such as Inconel 600 and Hastelloy, corrode slower than $0.01 \mathrm{~mm} / \mathrm{yr}$ in deoxygenated brines and sea water at $25^{\circ} \mathrm{C}$ (Braithwaite and Molecke 1978). In oxygenated solutions, corrosion rates rise to 0.1 to $0.2 \mathrm{~mm} / \mathrm{yr}$. If the presence of oxygen in the repository were 1 imited, these alloys might serve well. At $25^{\circ} \mathrm{C}$ these alloys are virtually unattacked in normal atmospheres and waters; acid salt solutions can be corrosive (see Table 3). Based on this cursory analysis, nickel-base alloys may be least suited to salt repositories; however, they may perform well in other repositories.

Hastelloy $\mathrm{C}$ has a tensile strength of about 100,000 psi and elongations of $10 \%$ (cast) to $60 \%$ (wrought sheet). Hastelloy $\mathrm{C}$ is an Ni-Mo-Cr-Fe-W alloy and will form thin complex oxide films that should minimize interaction with waste cores. The thermal expansion of Hastelloy $\mathrm{C}\left(11 \times 10^{-6},{ }^{\circ} \mathrm{C}\right)$ should match the waste cores well (see Table 4). The only potential fabrication options require pressing (HIP, hot press, or forge) at temperatures around $1000^{\circ} \mathrm{C}$, which should be compatible with most waste cores.

A nickel matrix would cost $0.04 \%$ of the value of electricity generated (Table 4 ), and a maximum of $2.5 \%$ of the U.S. consumption of nickel would go into nickel matrix HLW forms in the year 2000. In light of our dependence upon imports, the desirability of burying that much nickel should be evaluated. 
There are no unusual safety or health hazards with nickel-base alloys other than the hazards associated with handling metal powders.

Copper

Copper metals resist the atmosphere, fresh and salt waters, alkaline solutions (except those containing ammonia), and many salt solutions. Copper reacts with sulfur and sulfides to form copper sulfide; therefore, access to sulfur compounds must be limited. Copper metals usually corrode preferentially when coupled with high nickel alloys, titanium, or graphite. Pitting attack can occur on copper surfaces that have incomplete protective films, nonprotective deposits of scale, or other extraneous deposits. SCC can be controlled by proper alloy selection (notably those with less than 15\% $\mathrm{Zn}$ ), thermal stress relief, and control of the environment (elimination of mercury compounds or ammonia) (American Society for Metals 1979).

Careful selection and modification of the repository environment can be beneficial. Oxygen-free high-conductivity (OFHC) copper canisters designed by the Swedish KBS are expected to have a service life of hundreds of thousands of years when placed in a buffer material of highly compacted bentonite within a pre-Cambrian bedrock (gneiss, granite) repository (National Academy of Science 1980; Ahlstrom 1978). Under similar design conditions a copper matrix could be expected to exhibit outstanding barrier properties.

Copper-nickels (70\% $\mathrm{Cu}-30 \% \mathrm{Ni}$ and $90 \% \mathrm{Cu}-10 \% \mathrm{Ni}$ ) have the best general resistance to aqueous corrosion of all the commercially important copper alloys. They are superior to copper and copper alloys in resisting acid solutions and are highly resistant to SCC (American Soziety for Metals 1979).

A major feature of copper alloys is the varied fabrication possibilities applicable to HLW. Very fine copper powders have been hot pressed from 96 to $98 \%$ TD in just 10 to $100 \mathrm{~min}$ at $600^{\circ} \mathrm{C}$ and 10,000 psi. Copper $-10 \%$ tin powder mixtures are liquid phase sintered at 800 to $850^{\circ} \mathrm{C}$ (Hirshhorn 1969). Liquid phase sintering may also be applicable to $\mathrm{Cu}-\mathrm{Zn}, \mathrm{Cu}-\mathrm{Al}, \mathrm{Cu}-\mathrm{Si}$, and $\mathrm{Cu}-\mathrm{Be}, \mathrm{all}$ of which contain low-temperature melting eutectics. Alternatively, low melting metals such as zinc, aluminum, and tin might also be infiltrated into a copper powder matrix structure. Copper alloy matrices could also be cast; 
commercially pure copper $\left(1083^{\circ} \mathrm{C}\right.$ liquidus) could be cast at 1150 to $1200^{\circ} \mathrm{C}$; and beryllium copper alloy $\mathrm{C} 82800$ ( 1 iquidus $930^{\circ} \mathrm{C}$ ) could be cast at 965 to $1040^{\circ} \mathrm{C}$. Beryllium copper has high fluidity and a general corrosion resistance that is equal to or better than deoxidized copper (American Society for Metals 1979).

Cupronickel (90-10) alloy $\mathrm{C} 70600$ has a tensile strength of $350 \mathrm{MPa}$ $(51,000 \mathrm{psi})$ and an elongation of $35 \%$ in the annealed condition. Its thermal conductivity is good $(40 \mathrm{~W} / \mathrm{m}-\mathrm{K})$.

Since copper and nickel oxides are relatively unstable, it is not expected that a stable oxide reaction layer will develop between the cupronickel matrix and waste core. The extent of interdiffusion is hard to predict. The thermal expansion coefficient of cupronickel--17 $\times 10^{-6} /{ }^{\circ} \mathrm{C}--$ is about twice that of the waste cores; thus, the waste cores will be stressed in compression. Stress relief may be used to reduce the residual tensile stresses in the matrix.

A copper matrix would cost about $0.015 \%$ of the value of electricity generated (Table 4). A maximum of $0.23 \%$ of the U.S. consumption of copper would be used in copper matrices for HLW disposal in the year 2000 .

Stainless Steel

All types of stainless steel are likely to pit, groove, or corrode in crevices in sea water; and SS alloys as a group are far more susceptible to localized attack than copper-base and nickel-base alloys. Immersion in sea water is a more severe operating condition than industrial atmospheres; and in severe atmospheres, the grade, composition, and fabrication procedure are important. It is extremely unlikely that stainless steel will be an acceptable barrier matrix for use in salt repositories; however, in certain other engineered repository environments, it may provide an inexpensive option as a barrier matrix. Resistance of stainless steel to corrosion results from the presence of a thin hydrous oxide film that is stabilized by chromium on the surface of the metal. Passivation exists only in certain environments or under certain conditions. Although stainless steel is normally passive, it becomes active when exposed to corrosive solutions whose oxygenating power are low. The metal without the oxide film does not have good corrosion resistance; thus, by 
nature, stainless steel is usually quite good or very bad. In corrosive solutions it is seldom intermediate in performance. The presence of nickel in the high chromium steels greatly improves the resistance to certain nonoxygenated mediums (American Society for Metals 1961).

Typical tensile properties of a high-chromium, high-nickel stainless steel--for example, Type $310(25 \% \mathrm{Cr}-20 \% \mathrm{Ni})$ in the annealed condition--are $620 \mathrm{MPa}(90,000 \mathrm{psi})$ tensile strength and 45\% elongation (American Society for Metals 1961).

Stainless steel matrices can be formed by hot pressing or HIP at $1100^{\circ} \mathrm{C}$, probably with most waste cores. Some volatile elements in the waste core may distribute themselves throughout the matrix. At $1100^{\circ} \mathrm{C}$ stainless steel will likely form heavy nonprotective oxide layers where it contacts the waste, and the nature and extent of any matrix-to-waste core bond are difficult to predict. The coefficient of thermal expansion of Type $310 \mathrm{SS}$ is $18 \times 10^{-6} /{ }^{\circ} \mathrm{C}$, which is about twice that of waste cores; thus, the waste cores will be put in compression and the SS matrix will have high residual tensile stresses. Consideration will have to be given to stress-relieving the SS matrix to minimize the potential for stress corrosion.

A SS matrix would cost about $0.01 \%$ of the value of electricity generated (Table 4). A maximum of $0.5 \%$ of the U.S. consumption of stainless steel would be used for SS matrices for HLW disposal in the year 2000 .

$\underline{\text { Lead }}$

The data in Table 3 indicate that the corrosion rate of lead is high in $250^{\circ} \mathrm{C}$ brines and sea water and in $\mathrm{MgCl}_{2}$ solutions at $25^{\circ} \mathrm{C}$. Lead barrier matrices appear to be most applicable to low-temperature (near ambient), nonsalt repositories. Corrosion rates at $25^{\circ} \mathrm{C}$ in the atmosphere, ground waters, and sea waters are low.

Lead corrodes in aqueous solutions by anodic reaction, either entering solution or being converted to solid compounds. The most important determinant is usually the solubility and other physical characteristics of the corrosion products formed at the anode sites. The majority of these products are relatively insoluble lead salts that are deposited on the lead surfaces as 
impervious films that tend to stifle further attack. In most environments lead is cathodic to steel, aluminum, zinc, cadmium, and magnesium. With titanium and passivated stainless steel, lead is anodic and suffers accelerated attack. In general, lead alloys pit more deeply in poorly aerated soils (2.6-mm maximum pit depth in 11-yr tests) (American Society for Metals 1979).

Pure lead $(+99.9 \% \mathrm{~Pb})$ has a tensile strength of $1.4 \mathrm{MPa}(2000 \mathrm{ps} i$ ) and an elongation of $45 \%$. Lead is a good conductor of heat ( $35 \mathrm{~W} / \mathrm{m}-\mathrm{K}$ ) and has a very low creep strength that needs to be considered during design and alloy selection.

Because of their low melting point, lead and lead alloys can be cast at temperatures around $400^{\circ} \mathrm{C}$. Sintering or hot pressing of powder lead at about $300^{\circ} \mathrm{C}$ is a feasible method of forming a lead matrix with the waste cores separated by a web of lead. Apparently, lead reacts with glass waste cores slowly at molten lead temperatures and not at all in the solid state. Similar interaction would be expected with other waste core materials. Lead has a very high thermal expansion coefficient $\left(28 \times 10^{-6},{ }^{\circ} \mathrm{C}\right)$; however, its low yield and creep strength at room temperature should act to minimize residual stresses.

Lead matrix material costs $0.01 \%$ of the value of electricity generated (Table 4). Lead matrices would consume a maximum of $0.73 \%$ of the U.S. consumption of lead in the year 2000 .

Lead presents a health hazard due to inhalation of lead dust and fumes. Presumably, normal hot cell ventilation systems will adequately limit exposure of personnel to lead dust and fumes.

\section{Aluminum}

The data of Table 3 indicate that aluminum alloys corrode (disintegrate) rapidly at $250^{\circ} \mathrm{C}$. One alloy-- $\times 8001(1 \% \mathrm{Ni}, 0.5 \% \mathrm{Fe})-$ has a good resistance to high-purity water as high as $315^{\circ} \mathrm{C}$. However, at room temperature this alloy has poorer resistance than other alloys such as 1100,3003 , and 3004. Aluminum is thermodynamically reactive and owes its corrosion resistance to the aluminum oxide film that is bonded strongly to its surface and that will reform immediately if damaged in most environments. Aluminum is passive (protected by its 
oxide $f i l m$ ) in the $\mathrm{pH}$ range of about 4 to 8.5 , but beyond these limits it corrodes normally by pitting. Under most environmental conditions, aluminum is anodic to other metals and corrodes sacrifically; only magnesium and zinc are more anodic. Metal ions in solution (other than magnesium and $z i n c$ ) can be reduced by aluminum and deposited on the aluminum surface, thus setting up galvanic cells in which the aluminum is sacrificial. SCC is not found in metals generally selected for corrosion service (wrought alloys 1100, 3003, and 3004 and cast alloys containing silicon and less than $8 \%$ magnesium). Aluminum alloys have excellent resistance to weathering and to corrosion in most waters; however, water temperature, $\mathrm{pH}$ and conductivity, cathodic coupling, and metal ions in solution can accelerate corrosion. Because soils vary widely in mineral content, textures, permeability, moisture, $\mathrm{pH}$ and aeration, presence of organic matter, microorganisms, and electrical resistivity, corrosion performance of unprotected buried aluminum alloys varies considerably (American Society for Metals 1979). Aluminum barrier matrices should probably be limited to low-temperature, controlled-chemistry environments.

Typical tensile properties for cast alloy 413.0 (Al-12\% Si) are $300 \mathrm{MPa}$ $(43,000 \mathrm{psi})$ and $3 \%$ elongation.

Aluminum alloys will form thin, stable oxide surface layers, which may react at fabrication temperatures to form thin complex oxide layers with the waste core materials. The thermal expansion coefficient of alloy 413.0 is $20 \times 10^{-6} /^{\circ} \mathrm{C}$, which is much higher than for the waste cores that will be held in compression. Aluminum matrices have been fabricated in the past by casting. A powder metal approach using hot pressing at temperatures around $500^{\circ} \mathrm{C}$ could be used to fabricate waste forms having the waste cores separated by a web of aluminum matrix metal.

Of all the matrix metals selected, aluminum has the lowest cost--0.003\% of the value of electricity generated (Table 4). A maximum of $0.02 \%$ of U.S. consumption of aluminum would be used in matrices for HLW forms in the year 2000 . 
$\underline{\text { GLASS }}$

HLW glasses are being extensively studied. The effects of composition on the durability and physical properties of commercial glasses are well understood (Tooley 1974; Morey 1938; Shand 1958); and detailed data on compositional effects in HLW borosilicate glasses are now being developed (Ross and Mendel 1979). Commercial and waste glasses generally have comparable leach rates. Hence, the behavior of a glass matrix can be predicted with at least as much confidence as for any other material. The chemical durability of glass is really very good. At $25^{\circ} \mathrm{C}$, leach penetration (corrosion) rates have been measured as low as $10^{-2} \mathrm{~cm} / 1000 \mathrm{yr}\left(10^{-7} \mathrm{~g} / \mathrm{cm}^{2}\right.$-day) and as high as $1 \mathrm{~cm} / 1000 \mathrm{yr}$ (Jardine and Steindler 1978). In $250^{\circ} \mathrm{C}$ brines, Westsik and Turcotte (1978) measured a penetration rate of about $60 \mathrm{~cm} / 1000 \mathrm{yr}$ based on weight loss; in $100^{\circ} \mathrm{C}$ brines, the rate was about $2 \mathrm{~cm} / 1000 \mathrm{yr}$. Most of the above data was obtained from tests of relatively short duration (up to a week). Long-term corrosion rates would be expected to decrease due to limited leach water access and/or the development of protective layers of corrosion products. General effects of environment and glass composition on the corrosion of glass are discussed by Hench, Clark, and Yen-Bower (1978) and Shand (1958).

Some general physical properties of glasses are given in Table 5 along with specific properties. The range of properties obtainable is rather wide. The process of selecting a composition glass of high durability that is compatible with the waste core will not be attempted here; the logic is laid out by Tooley (1974). Suffice to say that a good thermal expansion match with the waste core is needed. Glass should be reasonably compatible with most waste cores and should form thin reaction layers.

Glass matrices can be formed by a sintering process. cold-pressed 95\% silica powder is pressureless sintered to about $98 \%$ density (impermeable to liquids). This method of fabrication (called "multiform") can be used with many glass compositions. The principal limitation results from a tendency of some glasses to devitrify during the firing operation. The properties of glass fabricated by this method are close to those obtained with other methods (Shand 1958). If pressureless sintering temperatures for a durable glass matrix are too high for the waste core, pressure-forming processes such as HIP or hot 


\section{TABLE 5. Representative Nonmetal Matrix Properties}

\begin{tabular}{|c|c|c|c|c|c|c|c|}
\hline Material & $\begin{array}{l}\text { Fabrication } \\
\text { Temperature, }{ }^{\circ} \mathrm{C}\end{array}$ & $\begin{array}{c}\text { Density, } \\
\text { g/cc }\end{array}$ & $\begin{array}{l}\text { Thermal } \\
\text { Expansion, } \\
10^{-6} /^{\circ} \mathrm{C} \\
\end{array}$ & $\begin{array}{l}\text { Young's } \\
\text { Modulus, } \\
\text { GPA }\end{array}$ & $\begin{array}{l}\text { Thermal } \\
\text { Conductivity, } \\
W / \mathrm{m}-\mathrm{K} \\
\end{array}$ & $\begin{array}{l}\% \text { of } \\
\text { Electricity } \\
\text { Value }(a) \\
\end{array}$ & $\begin{array}{l}\text { \% of U.S. } \\
\text { Consumption } \\
\text { in Year } 200 n(a)\end{array}$ \\
\hline $\begin{array}{l}\text { Glass }(b) \\
\text { Range } \\
\text { Borosilicate } \\
(\text { Corning } 7740)^{\circledR}\end{array}$ & $\begin{array}{l}400 \text { to } 1400 \\
820\end{array}$ & $\begin{array}{l}\text { 2.? } \begin{array}{l}\text { to } 8.0 \\
2.2\end{array}\end{array}$ & $\begin{array}{l}0.2 \text { to } 11.0 \\
3.3\end{array}$ & $\begin{array}{c}48.0 \text { to } 175.0 \\
63.0\end{array}$ & $\begin{array}{c}0.4 \text { to } 1.3 \\
1.2\end{array}$ & 0.002 & 4.3 \\
\hline $\begin{array}{l}\text { Polymer } \\
\text { EPOM Rubber } \\
\text { Polyphenylene Sulfide(c) }\end{array}$ & & $\begin{array}{l}0.9 \\
1.3\end{array}$ & 54.0 & 0.5 & 0.3 & 0.001 & 0.23 \\
\hline $\begin{array}{l}\text { Graphite } \\
\text { Pressed Powder } \\
\text { Manufactured Sheet }\end{array}$ & $\begin{array}{r}25 \\
2700\end{array}$ & $\begin{array}{l}2.1 \\
1.8\end{array}$ & 2.0 to 9.0 & 10.0 & 100 & 0.017 & 0.37 \\
\hline $\begin{array}{l}\text { Castable Refractory } \\
\text { H-W Castolast G(d) } \\
\left(94 \% \mathrm{Al}_{2} 03-6 \% \text { CaO) }\right.\end{array}$ & 25 & 2.7 & & & 2.0 & & \\
\hline $\mathrm{TiO}_{2}(\mathrm{e})$ & 1200 & 4.25 & 8.8 & 280.0 & 8.6 & 0.002 & 0.52 \\
\hline $\mathrm{Al}_{2} \mathrm{O}_{3}(\mathrm{e})$ & 1400 & 4.0 & 9.0 & 380.0 & 28.0 & 0.001 & 0.005 \\
\hline $\begin{array}{l}\operatorname{ZrO}_{2}(\mathrm{e}) \\
\text { (cubic stabilized) }\end{array}$ & 1300 & 5.5 & 10.8 & 138.0 & 1.8 & & \\
\hline
\end{tabular}

(a) Calculation of these values is discussed on page 11 .

(b) Tooley 1974

(c) Lynch 1975 .

(d) Harbison-Walker Refractories 1977.

(e) Lynch, Ruderer, and Duckworth 1966.

(B) Corning Glass Works, Corning, New York. 
pressing could be used to obtain highly dense glass matrix structures at considerably reduced temperatures. The viscous behavior of glasses is a distinct advantage during fabrication. Generally speaking, glasses are sintered and hot pressed at temperatures around the softening point $\left(10^{6.6} \mathrm{~N} \times \mathrm{S} / \mathrm{m}^{2}\right.$ or $10^{7.6}$ poise). For example, the softening temperature for Corning Code $7740^{\circledR}$ borosilicate glass is $820^{\circ} \mathrm{C}$. At these temperatures, the glass is fluid enough to act as an isostatic pressing medium to densify unsintered waste cores during hot pressing, thereby el iminating a separate sintering step.

It may be possible to form glass-ceramic matrices by these general methods with due attention given to the kinetics of nucleation, crystallization, and grain growth.

Borosilicate glass matrices would cost approximately $0.002 \%$ of the value of electricity generated (Table 5). Borosilicate glass matrices for HLW would consume a maximum of $4.3 \%$ of the U.S. production of borosilicate glass in the year 2000--a small but significant impact. At this level, glass producers should be notified in advance of the requirements for HLW. The potential impact on the much larger soda-lime glass production would be negligible.

Glass is a brittle material; its strength depends sensitively upon the presence of flaws, residual surface stress, and environment. Typical strengths of abraded annealed glass are 35 to $70 \mathrm{MPa}$ (5 to $10 \mathrm{ksi}$ ). Higher strengths are obtained by tempering and chemical strengthening (Tooley 1974).

The development of glass matrix materials using powder glass fabrication processes should be pursued. At some later date the work could be extended into glass-ceramics if the basic glass matrix development work indicated real potential.

\section{POLYMERS}

In general, polymers are stable in aqueous solutions, potentially inexpensive, and may be fabricated by a variety of low-temperature processes. However, polymers are relatively sensitive to radiation and elevated temperatures.

\footnotetext{
${ }^{\circledR}$ Corning Glass Works, Corning, New York.
} 
Skiens (Westerman et al. 1979) has reviewed polymers with respect to engineered barriers and found that many plastics are potentially capable of service at $250^{\circ} \mathrm{C}$ or to $10^{10}$ rad gamma dose. Subsequent screening tests by Skiens (Westerman et al. 1980) have identified two polymers that have demonstrated acceptable resistance to the separate effects of $250^{\circ} \mathrm{C}$ water and $5 \times 10^{8} \mathrm{rad}$ of cobalt-60 gamma radiation--ethylene propylene dimonomer (EPDM) rubbers and polyphenylene sulfide. Tests are needed to better define the long-term stability of these and other polymers to the simultaneous effects of radiation and high-temperature water. The estimated maximum gamma dose to an EPDM rubber matrix containing high-level commercial waste cores is $2 \times 10^{11}$ rads in 1000 yr. If defense wastes are substituted for the commercial waste, the dose drops to about $6 \times 10^{9}$ rads (see Appendix B).

A polymer matrix waste form would have to be designed with the properties of polymers in mind. For instance, polymers are basically poor conductors of heat $(\sim 0.2 \mathrm{~W} / \mathrm{m}-K)$; centerline temperatures of the waste form can exceed the recommended service temperature of the polymer. For example, a cursory analysis indicates that a matrix waste form with 50 vol\% glass waste cores from 5 -yr-old commercial waste and 50 vol\% polymer matrix in a 2 -ft diameter canister would have a centerline temperature of about $440^{\circ} \mathrm{C}$ for a surface temperature of $80^{\circ} \mathrm{C}$. In $30 \mathrm{yr}$ the centerline temperature would drop to $200^{\circ} \mathrm{C}$. The centerline temperature can be reduced with canister diameter; the 10-yr and $30-y r$ figures for a 1 -ft diameter canister would be $135^{\circ} \mathrm{C}$ and $110^{\circ} \mathrm{C}$, respectively. Diluting the waste loading of the waste cores would help; unfortunately, diluting the heat load by increasing the vol\% of polymer matrix would actually increase centerline temperatures since the polymer is a poorer conductor of heat than the waste core $(\sim 1.0 \mathrm{~W} / \mathrm{m}-\mathrm{K})$. Fortunately, polymer conductivity can be improved by the addition of a conductive filler such as graphite, which would be a prime candidate due to its extremely high leach resistance combined with its high thermal conductivity (25 to $170 \mathrm{~W} / \mathrm{m}-\mathrm{K}$ ).

The potential of polymer matrices should be evaluated through an engineering assessment of the stability of polymer matrices and methods of ameliorating the problem. 
Graphite has been found to react very slowly in water (Gray 1980; Fullam 1980). In $250^{\circ} \mathrm{C}$ deionized water the reaction rate is about $0.01 \mathrm{~cm} / 1000 \mathrm{yr}$ $\left(10^{-7} \mathrm{~g} / \mathrm{cm}^{2}\right.$-day); the rate extrapolated to $99^{\circ} \mathrm{C}$ is about $10^{-5} \mathrm{~cm} / 1000 \mathrm{yr}$ $\left(10^{-10} \mathrm{~g} / \mathrm{cm}^{2}\right.$-day $)$. These rates are orders of magnitude less than any other material measured to date. The theoretical potential of graphite as a barrier is tremendous. Pyrolytic carbon coatings for waste cores have been under development for some time (Rusin et al. 1978; Rusin, Gray, and Wald 1979). Graphite is also being considered as a potential canister or overpack material (Westerman et al. 1980) and has excellent potential as a barrier matrix. Fabrication of a matrix by the usual graphite fabrication processes poses two problems: graphitizing temperatures are over $2200^{\circ} \mathrm{C}$ and there is $\sim 20 \%$ of the residual porosity that needs to be sealed by some method.

Morgan (1981) has studied the problem of graphite barrier matrix fabrication and concluded that a powder pressing process has the most promise. Specially prepared graphite powders, either natural or synthetic, can be cold or warm compacted to over 90\% density; and strengths of some 1500 psi can be obtained (strength could be improved by mechanical working or heat treatment). Preliminary work by L. R. Bunnell at PNL has confirmed this; TDs of 95 to $97 \%$ of $2.2 \mathrm{~g} / \mathrm{cc}$ have been obtained by uniaxial pressing of a spectrographic grade of graphite powder at room temperature. Preliminary indications are that these compacts are permeable to water. The principal advantages of powder compaction are that it is done at temperatures compatible with all waste cores and that a minimum of porosity is left to be sealed.

Detrimental porosity can be filled in several ways (Morgan 1981):

- addition of a small amount of corrosion-resistant binder (e.g., glassy carbon precursor)

- organic impregnation with, for example, a glassy carbon precursor that bakes out well at low temperatures $\left(1000^{\circ} \mathrm{C}\right)$

- metallic impregnation by either wetting or nonwetting metals 
- vapor deposition (e.g., pyrolytic carbon)

- encapsulation in an envelope of another corrosion-resistant material, for example, zirconium from clad hull wastes.

All of the above porosity filling/sealing techniques have advantages and disadvantages that will not be discussed here. Considerable developmental efforts are needed in the pressing of powder graphite matrices, porosity filling/sealing, and evaluation of properties (including reactions with waste cores at processing temperatures, e.g., bake out at $1000^{\circ} \mathrm{C}$ ).

Based on the relatively high price of a manufactured graphite sheet, graphite matrices would cost about $0.02 \%$ of the value of electricity generated (Table 5). A maximum of about $0.4 \%$ of the U.S. consumption of graphite would be used in graphite matrices for HLW in the year 2000. The graphite matrix has one potentially attractive feature: It is a good mold material for casting of many metals; therefore, it should be possible to cast a corrosion-resistant metal envelope around the graphite matrix waste form. Even zirconium cladding hulls (Dillon, Kemper, and King 1979) could be used for the envelope.

In summary, the compacted graphite powder matrix approach should be pursued with the objective of achieving zero permeability directly from compaction. If necessary, methods of sealing/filling the porosity should be pursued.

\section{CERAMICS}

Ceramic materials may have good barrier properties and are being studied as both primary waste forms and as engineered barriers (Cornman 1980). With the exception of $\mathrm{TiO}_{2}$, known ceramics having good corrosion resistance do not appear to be applicable to matrices because their lowest fabrication temperatures for hot pressing or HIP are too high for the waste cores that have been developed to date.

Fullam (1980) has leach tested a variety of potential ceramic materials and graphite for engineered barriers. Graphite, alumina ( $>99 \% \mathrm{Al}_{2} \mathrm{O}_{3}$ ), $\mathrm{TiO}_{2}$, and $\mathrm{ZrO}_{2}$ all had leach rates at $250^{\circ} \mathrm{C}$ of less than $20 \mathrm{~cm} / 1000 \mathrm{yr}$; however, the $\mathrm{TiO}_{2}$ cracked during leach testing. Of these ceramic materials, the lowest hot pressing temperature found in a cursory literature survey was for $\mathrm{TiO}_{2}$ of 
unknown purity; $100 \%$ density was attained at $1200^{\circ} \mathrm{C}$ (Jackson and Dolmer 1960). At this temperature the volatility of cesium and other radionuclides in the waste core is high and the matrix becomes contaminated with radionuclides. For instance, cesium losses in $4-h$ exposures at $1200^{\circ} \mathrm{C}$ were $100 \%$ for $72-68$ glass and about 10\% for supercalcine (Rusin, Wald, and Gray 1979); over 50\% of the cesium is lost from synroc B during sintering or hot pressing at $1300^{\circ} \mathrm{C}$ (Cornman 1980).

Even if hot pressing temperatures could be lowered for these ceramic matrices they will have a high tendency to crack due to thermal stresses and anisotrophy; their high elastic moduli and high fabrication temperatures enhance cracking. Other materials promise equal or better corrosion resistance with fewer fabrication and cracking problems. It is therefore recommended that ceramic matrix development not be pursued.

\section{CASTABLES}

Castable refractories (often called refractory concretes) are easily cast by a variety of methods including pouring, trowelling, gunning, and ramming. A castable waste form would consist of the waste core (as the large aggregate) in a cemented matrix composed of a fine, corrosion-resistant aggregate (e.g., $\mathrm{Al}_{2} \mathrm{O}_{3}$ sand) and a cement bond. The cement and its interaction with the aggregates are largely responsible for the strength, refractoriness, and corrosion resistance properties of the resulting concrete. Typical castables use aluminous or portland cement hydraulic bonds sometimes augmented by or replaced by a phosphate bond (Wygant 1958; Harbison-Walker Refractories 1977). A wide variety of other cement bonds are available and potentially applicable to the peculiar requirements of HLW disposal; Wygant (1958) has given an excellent review of the subject. The entire subject of cement bonding is broad and complex and will not be discussed here.

In contrast to the ease with which castables can be fabricated, there are little data available that relate directly to the HLW matrix waste form; and much of the information on castables is proprietary. Castable refractories 
are developed for their high-temperature properties $\left(>1000^{\circ} \mathrm{C}\right.$ ) and are infrequently used at lower temperatures or in radiation environments. There is, however, considerable experience with ordinary portland cement concrete in the surface and near-surface environment.

Lokken (1978) has reviewed radioactive waste immobilization in concrete where HLW calcine is blended with hydraulic cement to form a homogeneous mixture. Lokken points out some significant processing problems that would be common to a castable matrix. Radiolysis products (basically $\mathrm{H}_{2}$ and $\mathrm{O}_{2}$ ) will have to be vented or contained during mixing, casting, and curing. The castable will have to be cooled during those processing steps to prevent boiling of the water. Gas pressures in the canister will have to be maintained high enough to insure that no boiling of unbound water occurs and low enough to insure canister integrity and safety. After curing for 2 or 3 days, the canister is vented until all unbound water is driven off. Further venting may be necessary during long-term storage due to the buildup of radiolysis products.

In considering castables with high-quality barrier matrix properties for HLW disposal there are two areas that need to be addressed in addition to fabrication:

- corrosion resistance of the cemented matrix while in contact with the waste core

- long-term radiolysis effects due to gamma ray exposure of the bulk matrix and alpha ray exposure of the waste core-to-matrix bond.

Bibler (1978) investigated the extent of gas production from radiolysis of concrete containing Savannah River Plant waste and estimated that during the first $300 \mathrm{yr}$ hydrogen pressures of 8 to 28 psi would be produced. After 300 yr a minimum nitrous oxide pressure of $<60$ psi would be present; hydrogen and oxygen pressures would increase to $>200 \mathrm{psi}$. The pressures generated were found to increase with dose rate.

Dose rates for HLW may be one to two orders of magnitude higher than for those studied at Savannah River (Lokken 1978). Radiolytic gas generation depends upon the interaction of all chemical species present in the concrete, 
the products of radiolysis, and the subsequent reaction of the radiolys is products with each other and the original concrete constituents. Therefore, Bibler's results cannot be extrapolated to other concrete compositions.

Lokken (1978) summarized data on room temperature leach rates in deionized water for concrete waste forms: Leach rate decreased with time. In a 1008-h test, high alumina cement (with no HLW content) had a leach rate of $2 \mathrm{x}$ $10^{-4} \mathrm{~g} / \mathrm{cm}^{2}$-day (approximate penetration rate of $20 \mathrm{~cm} / 1000 \mathrm{yr}$ ). High alumina cement with $10 \%$ cesium-loaded zeolite had a leach rate of $5.1 \times 10^{-5} \mathrm{~g} / \mathrm{cm}^{2}$-day $(5 \mathrm{~cm} / 1000 \mathrm{yr}$ ). Type I portland cement with $10 \%$ cesium-loaded zeolite had a leach rate of $1.7 \times 10^{-4} \mathrm{~g} / \mathrm{cm}^{2}$-day $(17 \mathrm{~cm} / 1000 \mathrm{yr})$. It is assumed that these penetration rates will increase with temperature. Radiation tended to decrease leach rates up to 20 times, and heating to $400^{\circ} \mathrm{C}$ for 1 month before testing at room temperatures increased leach rates as much as 500 times.

The above leach rate data show little promise for cemented matrix waste forms, and no development work is recommended. If a castable matrix development program is pursued, it should begin with the following steps. A detailed literature survey on cements applicable to castable matrices should be done, and industrial developers and suppliers should be contacted to bring forth proprietary products. Selected potential cement-fine aggregate combinations should be subjected to scouting leach tests to select the most promising combinations. A minor amount of bench-scale work should be done to demonstrate the thermal and mechanical compatibility of the castable with the waste form. Further developments should be based upon the promise of the materials investigated. 


\section{REFERENCES}

Ahlstrom, Per-Eric. 1978. "Ceramic and Pure-Metal Canisters in Buffer Material." In Proceedings of the Conference on High-Level Radioactive Solid Waste Forms, ed. L. A. Casey, pp. 283-316. NUREG/CP-0005, National Technical Information Service, Springfield, Virginia.

Alternative Waste Form Peer Review Pane1. 1981. The Evaluation and Review of Alternative Waste Forms for Immobilization of High-Level Radioactive Wastes, Report Number 3. DOE/TIC-11472, U.S. Department of Energy, Office of Nuclear Waste Management, Washington, D.C.

American Society for Metals. 1961. Metals Handbook, 8th Edition, Vol. 1, Properties and Selection of Metals. Metals Park, Ohio.

American Society for Metals. 1978. Metals Handbook, 9th Edition, Vol. 1, Properties and Selection: Irons and Steels. Metals Park, Ohio.

American Society for Metals. 1979. Metals Handbook, 9th Edition, Vol. 2, Properties and Selection: Nonferrous Alloys and Pure Metals. Metals Park, ohio.

Bibler, N. E. 1978. Radiolytic Gas Production from Concrete Containing Savannah River Plant Waste. DP-1464, Savannah River Laboratory, Aiken, South Carolina.

Braithwaite, J. W., and M. Molecke. 1978. "High-Level Waste Canister Corrosion Studies Pertinent to Geologic Isolation." In Proceedings of the Conference on High-Level Radioactive Solid Waste Forms, ed. L. A. Casey, pp. 241-277. NUREG/CP-0005, National Technical Information Service, Springfield, Virginia.

Cornman, W. R., compiler. 1980. Composite Quarterly Technical Report - LongTerm High-Level Waste Technology, July-September 1979. DP-79-15-3, Savannah River Laboratory, Aiken, South Carolina.

Dillon, R. L., R. S. Kemper, and R. R. King. 1979. "Decontamination and Densification of Chop-Leach Cladding Residues." In Nuclear Waste Management Quarterly Progress Report July Through September 1978, compiled by A. M. Platt and J. A. PoweTT. PNL-2378-3, Pacific Northwest Laboratory, Richland, Washington.

Friedman, G. I., and M. J. Kazaroff. 1971. "Properties of Hot Pressed Titanium Alloy Powders for Cryogenic Applications." In Modern Developments in Powder Metallurgy, Vol. 5, ed. H. H. Hausner. Plenum Press, New York.

Fullam, H. T. 1980. Use of Ceramic Materials in Waste-Package Systems for Geologic Disposal of Nuclear Wastes. PNL-3447, Pacific Northwest Laboratory, Richland, Washington. 
Gray, W. J. 1980. "Reaction of Graphite in Water and Its Implications for Radioactive Waste Storage." Radioactive Waste Management 1:105.

Harbison-Walker Refractories, Dressler Industries. 1977. The Handbook of Castable Refractories. Pittsburgh, Pennsylvania.

Hench, L. L., D. E. Clark, and E. L. Yen-Bower. 1978. "Surface Leaching of Glasses and Glass-Ceramics." In Proceedings of the Conference on High-Level Radioactive Solid Waste Forms, ed. L. A. Casey, pp. 199-238. NUREG/CP-0005, National Technical Information Service, Springfield, Virginia.

Hirshhorn, J. S. 1969. Introduction to Powder Metallurgy. American Powder Metallurgy Institute, New York.

Jackson, J. D., and W. K. Boyd. 1970. "Stress Corrosion Cracking in Titanium and Titanium Alloys." In The Science, Technology and Application of Titanium, eds. R. I. Jaffee and N. E. Promisel. Pergamon Press, New York.

Jackson, J. S., and P. F. Dolmer. 1960. "Hot Pressing Refractory Hard Materials." In Special Ceramics, ed. P. Popper. Academic Press, New York.

Jardine, L. J., and M. J. Steindler. 1978. A Review of Metal Matrix Encapsulation of Solidified Radioactive High-Level Waste. ANL-78-19, Argonne National Laboratory, Argonne, Illinois.

Lokken, R. 0. 1978. A Review of Radioactive Waste Immobilization in Concrete. PNL-2654, Pacific Northwest Laboratory, Richland, Washington.

Lynch, C. T., ed. 1975. Handbook of Materials Science, Volume III: Nonmetallic Material and Applications. CRC Press, CTeveland, Ohio.

Lynch, J. F., C. G. Ruderer, and W. H. Duckworth. 1966. Engineering Properties of Selected Ceramic Materials. American Ceramic Society, Columbus, ohio.

Mendel, J.E., et al. 1981. A State-of-the-Art Review of Materials Properties of Nuclear Waste Forms. PNL-3802, Pacific Northwest Laboratory, Richland, Washington.

Morey, G. W. 1938. The Properties of Glass. Reinhold, New York.

Morgan, W. C. 1981. Graphite Materials for Nuclear Waste Isolation. PNL-3556, Pacific Northwest Laboratory, Richland, Washington.

National Academy of Science. 1980. A Review of the Swedish KBS-II Plan for Disposal of Spent Nuclear Fuel. Washington, D.C.

Neumann, W. 1979. "Embedding Methods of Solidified Waste in Metal Matrices." In Ceramics in Nuclear Waste Management, eds. T. D. Chikalla and J. E. Mendel. CONF-790420, National Technical Information Service, Springfield, Virginia. 
Park, U. Y., and K. R. Yates. 1979. "Nuclear Fuel Projections and Spent Fuel Accumulation." Power Engineering December:64-65.

Peterseim, F. D. 1957. Hazards and Safety Precautions in the Fabrication and Use of Titanium. Titanium Metallurgical Laboratory Report No. 63, Battelle Memorial Institute, Columbus, Ohio.

Ross, W. A., et al. 1978. Annual Report on the Characterization of High-Level Waste Glasses. PNL-2625, Pacific Northwest Laboratory, Richland, Washington.

Ross, W. A., and J. E. Mendel. 1979. Annual Report on the Development and Characterization of Solidified Forms of High-Level Wastes: 1978. PNL-3060, Pacific Northwest Laboratory, Richland, Washington.

Rusin, J. M., et al. 1978. Multibarrier Waste Forms Part I: Development. PNL-2668-1, Pacific Northwest Laboratory, Richland, Washington.

Rusin, J. M. 1980. A Review of High-Level Waste Form Properties. PNL-3035, Pacific Northwest Laboratory, Richiand, Washington.

Rusin, J. M., W. J. Gray, and J. W. Wald. 1979. Multibarrier Waste Forms Part II: Characterization and Evaluation. PNL- 2668-2, Pacific Northwest Laboratory, Richland, Washington.

Schwope, A. D. 1961. "Titanium and Zirconium Powder Metallurgy." In Powder Metallurgy, ed. W. Leszynski. Interscience Publishers, New York.

Shand, E. B. 1958. Glass Engineering Handbook. McGraw-Hill, New York.

Shannon, D. W. 1977. Corrosion of Iron-Base Alloys Versus Alternate Materials in Geothermal Brines. PNL-2456, Pacific Northwest Laboratory, Richland, Washington.

Slate, S. C., et al. 1978. "Stresses and Cracking in High-Level Waste Glass." In Proceedings of the Conference on High-Level Radioactive Solid Waste Forms, ed. L. A. Casey, pp. 393-455. NUREG/CP-0005, National Technical Information Service, Springfield, Virginia.

Stough, D. W. 1957. Memorandum on the Corrosion Properties of Titanium and Titanium Alloys. Titanium MetalTurgical Laboratory, Battelle Memorial Institute, Columbus, Ohio.

Tooley, F. V. 1974. The Handbook of Glass Manufacture. Vols. 1 and 2. Magazines for Industry, Inc., New York.

U.S. Bureau of Mines. 1975. Mineral Facts and Problems. U.S. Government Printing Office, Washington, D.C. 
U.S. Energy Research and Development Administration. 1976. Alternatives for Managing Wastes from Reactors and Post-Fission Operations in the LWR Fue Cycle, Vol. 1. ERDA 76-43, National Technical Information Service, Springfield, Virginia.

Watts, R. L., et al. 1980. The Evaluation of Critical Materials for Five Advanced Design Photovoltaic Cells with an Assessment of Indium and Gallium. PNL-3319, Pacific Northwest Laboratory, Rich Tand, Washington.

Westerman, R. E., et al. 1979. Preliminary Conceptual Designs for Advanced Packages for the Geologic Disposal of Spent Fuel. PNL-2990, Pacific Northwest Laboratory, Richland, Washington.

Westerman, R. E., et al. 1980. Investigation of Metallic, Ceramic, and Polymeric Materials for Engineered Barrier Applications in Nuclear Waste Packages. PNL-3484, Pacific Northwest Laboratory, Richland, washington.

Westsik, J.H., Jr., and R. P. Turcotte. 1978. Hydrothermal Reactions of Nuclear Waste Solids - A Preliminary Study. PNL-2759, Pacific Northwest Laboratory, Richland, Washington.

Wygant, J. F. 1958. "Cementitious Bonding in Ceramic Fabrication." Ceramic Fabrication Processes, ed. W. D. Kingery. John Wiley \& Sons, New York. 


\section{ACKNOWLEDGMENTS}

R. E. Westerman provided the much needed catalyst for this study as well as a major input in the development of matrix criteria; our many discussions were fruitful. A. M. Nolan provided estimates of radiation doses to the matrix. As always in a study this broad, numerous other Pacific Northwest Laboratory ( $P$ NL) personnel made contributions that shaped and moved this work to its final form. Particular thanks are extended to the following reviewers: J. M. Rusin; W. C. Morgan; T. D. Chikalla; C. R. Hann; R. S. Kemper; R. G. Nelson; and E. L. Courtright. S. K. Edler edited this report. 
APPENDIX A

THE BARRIER MATRIX CONCEPT 
APPENDIX A

\section{THE BARRIER MATRIX CONCEPT}

In the idealized barrier matrix waste form (see Figure A.1) the envelope, the film (or membrane) of matrix material that separates the waste cores, and the bond between the matrix and waste core are the important structural features. In the following discussions it is assumed that the matrix material is impermeable and highly corrosion resistant (corrodes at the same rate as the waste core or slower). The waste core is assumed to be a high-quality, impermeable sphere of glass (e.g., borosilicate glass) or crystalline ceramic (e.g., supercalcine, synroc, crystallized glass, or titanate ceramic).

For simplicity, the following discussions will be based upon corrosion penetration rates rather than mass leach rates. The rate at which leach waters penetrate is related to the mass leach rate by the simple expression:

$$
\begin{aligned}
\text { Penetration Rate } & =365.25 \mathrm{~L} / \rho \mathrm{cm} / \mathrm{yr} \\
& =3.65 \times 10^{5} \mathrm{~L} / \rho \mathrm{cm} / 1000 \mathrm{yr}
\end{aligned}
$$

where $L=$ leach rate in $\mathrm{g} / \mathrm{cm}^{2}$-day

$\rho=$ material density in $\mathrm{g} / \mathrm{cm}^{3}$.

Penetration rates in $\mathrm{cm} / 1000 \mathrm{yr}$ are approximately equal to $10^{5}$ times the leach rate (exact for a density of $3.65 \mathrm{~g} / \mathrm{cm}^{3}$ ).

\section{ENVELOPE}

The outer envelope of pure protective material (see Figure A.1) completely encases the matrix-waste mixture. The envelope thickness is chosen to provide a 1000-yr barrier to leach waters. For example, a 1-cm thick envelope will have at least a $1000-y r$ life if its corrosion penetration rate is less than $1 \mathrm{~cm} / 1000 \mathrm{yr}$ (roughly equal to a leach rate of $1 \times 10^{-5} \mathrm{~g} / \mathrm{cm}^{2}$-day). 


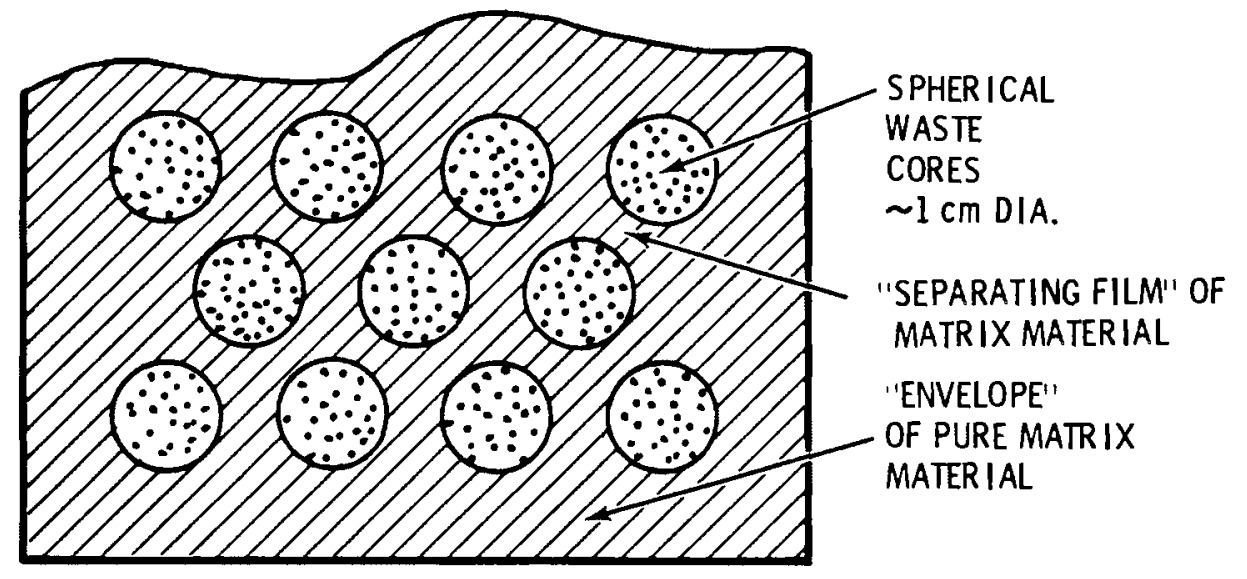

FIGURE A.1. Idealized Barrier Matrix Waste Form

An important feature of the envelope is that it is continuous with the matrix. A crack or pit that completely penetrates the envelope exposes only a small area of matrix waste form to leach waters. By comparison, the same crack or pit in a canister would potentially expose the whole outer surface area of a waste form to leach waters. If the envelope is penetrated and leach waters reach the waste cores, the leaching behavior of the matrix waste form depends upon the extent of bond between the matrix and waste core and the thickness of the separating film of matrix material.

\section{SEPARATING FILM}

The separating film (see Figure A.1) separates the waste cores and forms a coating of matrix material around each waste core. If the outer layer of waste cores is being leached, the adjacent waste cores are protected by the separating film of matrix material. The separating film, like the envelope, is designed for a given life. For example, at a matrix corrosion rate of $1 \mathrm{~cm} / 1000 \mathrm{yr}$, the separating film must be $0.2 \mathrm{~cm}$ thick for a 200-yr life.

The thickness of the separating layer can be increased by increasing the volume percent (vol\%) of matrix. Alternatively, if the vol\% matrix is held constant, increasing the waste core diameter will increase the separating layer thickness; or more precisely, at constant vol\% matrix, the separating film thickness is proportional to the waste core diameter. 
The separating film would be valued most highly under conditions where the matrix corrodes very slowly. For example, in $250^{\circ} \mathrm{C}$ leach waters, a $0.2-\mathrm{cm}$ separating film of titanium would have a life exceeding $333 \mathrm{yr}(0.0006 \mathrm{~cm} / \mathrm{yr})$ (Braithwaite and Molecke 1978) or a 0.2-cm impermeable graphite film would have a life of $20,000 \mathrm{yr}\left(10^{-5} \mathrm{~cm} / \mathrm{yr}\right)$ (Gray 1980).

The separating film is also highly important when there is no bond between the matrix and the waste cores. If a separating film of matrix material were not present (if the waste cores were touching one another) and if the waste cores were not bonded to the matrix, leach waters could wick through the whole structure of the matrix waste form, wetting every waste core surface. In this case the matrix does not function as a high-quality barrier. This combination-waste cores touching one another and not bonded to the matrix--is generally to be avoided if the matrix is to function as a true barrier.

\section{MATRIX-TO-WASTE CORE BOND}

What happens when a waste core is contacted by leach waters depends upon the extent of bonding between the waste core and matrix material (see Figure A.1). If the waste core is bonded to the matrix and the bond layers (if present) corrode no faster than the waste core itself, the corrosion progresses from one side of the waste core to the other. In this case the separating film is not called upon to perform as a barrier until the complete waste core is leached away. Conversely, in the absence of a bond the whole waste core surface as well as the separating film is wetted and begins to corrode immediately.

At a constant leach rate, the unbonded waste core will be leached away in half the time of a bonded waste core. Because the separating film begins to corrode immediately, the time required for leach water to reach the adjacent waste core is reduced.

If a matrix-to-waste core bond is formed, the reaction layers must be leach resistant and the bond strength must be greater than the thermally induced stresses at the matrix-waste core interface. According to Kingery (1960, p. 478), the thermal expansion-induced stresses are approximated by 


$$
\sigma_{i}=\frac{E}{3(1-2 \mu)}\left(\alpha_{r}-\alpha_{i}\right) \Delta T
$$

where $\alpha_{r}$ and $\alpha_{i}=$ the average volume expansion coefficient and the volume expansion coefficient for particle $i$

$$
\begin{aligned}
\Delta T & =\text { the temperature change from the stress-free state } \\
E & =\text { the elastic modulus } \\
\mu & =\text { Poisson's ratio. }
\end{aligned}
$$

According to this relationship, the thermally induced stresses at the matrix-to-waste core interface can be lowered and thus the bond preserved by:

- a better coefficient of thermal expansion match for the matrix and waste core $\left(\alpha_{r}-\alpha_{j}\right)$

- lower fabrication temperature (stress-free state), which lowers $\Delta T$

- changing the elastic properties, $E$ and $\mu$, if possible.

Selecting a matrix material and the process to achieve good bonding may be complex and difficult in some cases. Choices made for bonding characteristics may compromise barrier properties; for this reason, the decision may be made to not have bonding and simply separate the waste cores with a corrosionresistant film of matrix material.

\section{ANCILLARY EFFECTS OF INCREASED MATRIX VOLUME}

The barrier matrix properties just discussed are gained at the expense of reducing the vol\% of waste cores. There are some positive aspects to the reduced waste loading in addition to the barrier values of the matrix. The obvious disadvantage is that the total volume of the matrix waste form is increased. Increased costs are incurred for matrix material and perhaps, but not necessarily, for repository hole drilling.

To store the same amount of waste cores with an increased matrix volume, two simple choices are available:

- increase the number of canisters - Extra holes must be drilled in the repository and the canister spacings will be smaller. There is no apparent advantage to this choice. 
- increase the canister diameter while maintaining the same number (and depth) of repository holes - The resulting geometric relationships between vol\% matrix, separating film thickness, and canister diameter are exemplified in Figure A.2. There are some distinct heat transfer advantages to this choice that result in both reduced surface and centerline temperatures in the waste form as the vol\% of matrix increases. The reduced surface temperature will result in reduced leach rates. The proof of this concept of increased canister diameter is provided below.

Both conductive and convective heat transfer at the waste form surface are area dependent since temperature differences are inversely proportional to the heat transfer area (Baumeister 1978, p. 4-61). Since the heat transfer area of a canister increases roughly in proportion to the diameter, the approximate temperature increase between the repository and the waste form surface is inversely proportional to the canister diameter. Therefore, larger diameters lead to reduced waste form surface temperature. Radiative heat transfer, while not as sensitive to area, also reduces surface temperatures with increased surface area.

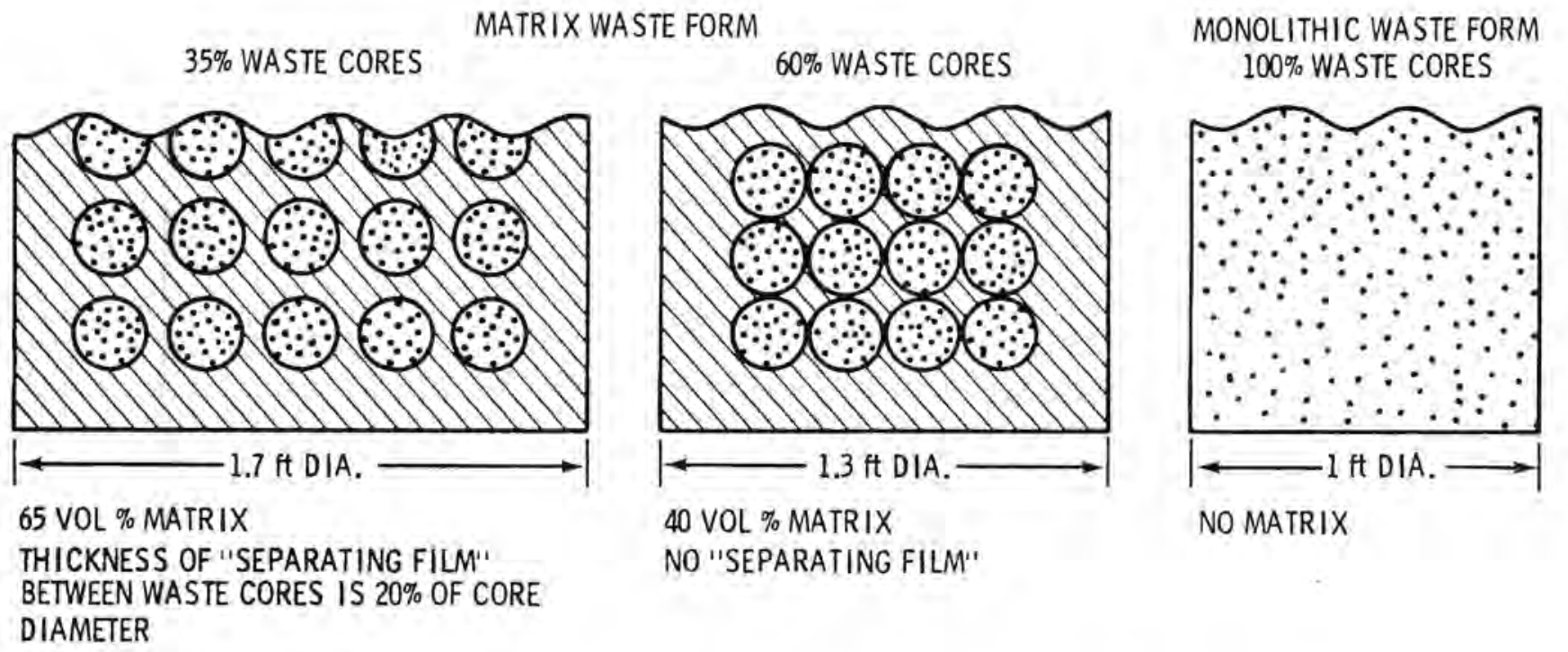

FIGURE A.2. Geometric Relationships at Constant Waste Core Mass 
In some cases the temperature rise between the repository and the waste form surface is about $200^{\circ} \mathrm{C}$ (Office of Waste Isolation 1978). In those cases the increased canister diameter will markedly reduce leach rates because leach rates are very sensitive to temperature (Westsik and Turcotte 1978, p. 23).

The effect of increased matrix volume on waste form centerline temperatures can be investigated using the following expression (Office of Waste Isolation 1978; Jardine and Steindler 1978, p. 40):

$$
\Delta T=\frac{q D^{2}}{16 k}
$$

where $\Delta T=$ temperature $r$ ise between the surface and the center of the matrix waste form

$q=$ volumetric heat generation rate of the matrix-waste core mixture

$D$ = waste form (canister) diameter

$k=$ thermal conductivity of the matrix-waste core mixture.

If we define $q_{w}$ as the volumetric heat generation rate of the waste core and $p$ as the volume fraction waste cores, then:

$$
q=q_{w} p
$$

If $V_{0}$ is the volume of a monolith ( $100 \%$ waste cores), then the matrix waste form volume $V$ is:

$$
V=\frac{V_{0}}{p}=\frac{\pi D^{2}}{4}(h)
$$

where $D$ is the waste form diameter (or canister inside diameter) and $h$ is the waste form height. Rearranging Equation (A.4) as

$$
D^{2}=\frac{4 V_{0}}{p \pi h}
$$


and substituting Equations (A.3) and (A.5) into (A.2) results in

$$
\Delta T_{\text {waste }}=\frac{q_{w} V_{0}}{4 k \pi h}
$$

Since everything except $k$ in Equation (A.6) is a constant with increasing matrix volume, $\Delta T_{\text {waste }}$ is inversely proportional to the conductivity of the matrix-to-waste core mixture or $\Delta T_{\text {waste }} \propto 1 / k$. The conductivity of the mixture $k$ is always improved by adding a greater vol\% of matrix as long as the matrix material is a better conductor than the waste core (Kingery 1960, Equation 14.36). Waste core conductivities are rather poor--typically about $1.0 \mathrm{~W} / \mathrm{m}-\mathrm{K}$; and every potential barrier matrix material has equal or better conductivity, except for polymers $(-0.2 \mathrm{~W} / \mathrm{m}-\mathrm{K})$. Fortunately, polymer conductivity could be raised to over $1.0 \mathrm{~W} / \mathrm{m}-\mathrm{K}$ by adding a conductive (and highly corrosion-resistant) filler such as graphite (25 to $170 \mathrm{~W} / \mathrm{m}-\mathrm{K})$. Therefore, increasing the matrix volume should always tend to increase the conductivity of the matrix waste form and consequently tend to reduce centerline temperatures in addition to reducing the surface temperature. 


\section{REFERENCES}

Baume ister, T., ed. 1978. Mark's Standard Handbook for Mechanical Engineers. 8th ed. McGraw-Hill, New York.

Braithwaite, J. W., and M. Molecke. 1978. "High-Level Waste Canister Corrosion Studies Pertinent to Geologic Isolation." In Proceedings of the Conference on High-Level Radioactive Solid Waste Forms, ed. L. A. Casey, pp. 241-277. NUREG/CP-0005, NationaT Technical Information Service, Springfield, Virginia.

Gray, W. J. 1980. "Reaction of Graphite in Water and Its Implications for Radioactive Waste Storage." Radioactive Waste Management 1:105.

Jardine, L. J., and M. J. Steindler. 1978. A Review of Metal Matrix Encapsulation of Solidified Radioactive High-Level waste. ANL-78-19, Argonne National Laboratory, Argonne, Illinois.

Kingery, W. D. 1960. Introduction to Ceramics. John Wiley Sons, Inc., New York.

Office of Waste Isolation. 1978. "Thermal Analysis." Technical Support for GEIS: Radioactive Waste Isolation in Geologic Formations. Vol. 19. Y/OWI/TM-36/19, Oak Ridge, Tennessee.

Westsik, J. H., Jr., and R. P. Turcotte. 1978. Hydrothermal Reactions of Nuclear Waste Solids - A Preliminary Study. PNL-2759, Pacific Northwest Laboratory, Richland, Washington. 
APPENDIX B

MATRIX RADIATION DOSE ESTIMATION

A. M. Nolan 
APPENDIX B

MATRIX RADIATION DOSE ESTIMATION

\section{INTRODUCTION}

As part of the ongoing waste management program at Pacific Northwest Laboratory (PNL), alternative forms for nuclear waste disposal are being considered to see if any are preferable to the reference monolithic borosilicate glass waste form. One of these alternative waste forms (AWFs) consists of small cores (i.e., pellets or marbles) of solidified waste in a matrix material. Several waste solidification methods and matrix materials are being considered (see Tables B.1 and B.2).

The matrix materials will be subjected to high radiation fields for long periods of time. It is important to know what level of dose is experienced by these materials to predict their chemical and mechanical behavior after years of exposure. The purpose of this study is to estimate the doses to the matrix materials as a function of waste source, solidified form, and time.

\section{GAMMA DOSES}

For the gamma dose calculation, the QADP5A point-kernal code was used. QADP5A was developed from QAD (Malenfant 1967) using code modifications contained in QADHD (Lahti 1967). A combination of explicitly modeled spheres and

TABLE B.1. Candidate Solidified Waste Cores

\begin{tabular}{|c|c|}
\hline Waste Cores & Density, $\mathrm{g} / \mathrm{cm}^{3}$ \\
\hline Borosilicate Glass & 3.0 \\
\hline Supercalcine & 3.7 to 4.9 \\
\hline Synroc B & 4.5 \\
\hline Glass-Ceramic Celsian & 3.1 to 3.7 \\
\hline
\end{tabular}


TABLE B.2. Candidate Matrix Materials

\begin{tabular}{|c|c|}
\hline Material & Density, $\mathrm{g} / \mathrm{cm}^{3}$ \\
\hline EPOM Rubber & 0.9 \\
\hline Polyphenylene Sulfide & 1.3 \\
\hline Graphite & 2.1 \\
\hline Glass, e.g., Corning code $7900^{(a)}$ & 2.18 \\
\hline $\mathrm{Al}-12 \% \mathrm{Si}$ & 2.66 \\
\hline $\begin{array}{l}\text { Castable Refractory } \\
\text { e.g., H-W Castolast G }\end{array}$ & 2.7 \\
\hline Glass, e.g., Corning code $0120^{(a)}$ & 3.05 \\
\hline Titanium & 4.5 \\
\hline $\mathrm{Pb}-10 \% \mathrm{Sn}$ & 10.5 \\
\hline
\end{tabular}

(a) Corning Glass Works, Corning, New York.

(b) Harbison-Walker Refractories, Pittsburgh, Pennsylvania.

homogenized regions was used to estimate the dose rates within the matrix material. No significant variation in radiation levels was found at various positions within the matrix. This is a result of assuming an infinite array of waste cores. The gamma dose would be lower near the edge of a finite core array.

Two of the matrix materials were chosen to represent the range of material densities to be considered: $\operatorname{EPDM}^{(a)}$ rubber $\left(0=0.9 \mathrm{~g} / \mathrm{cm}^{3}\right)$ and the $90 \%$ $\mathrm{Pb}-10 \% \mathrm{Sn}$ alloy $\left(\rho=10.5 \mathrm{~g} / \mathrm{cm}^{3}\right)$. The radiation levels found in these two matrices should bracket the range for a given waste core type.

Two waste sources were considered for this study: Savannah River Laboratory (SRL) defense wastes and a high-level commercial waste stream referred to as PW-9 (Ross et al. 1978, pp. 3-8). For the SRL defense wastes, gamma ray source strengths and glass compositions were given by Landon (1980). Source terms for the PW-9 commercial wastes were obtained using the ORIGEN code (Bell 1973) to provide a radionuclide inventory typical of high-level wastes (HLW) resulting from light water reactor (LWR) fuel burnup. The ORIGEN code also

(a) Ethylene propylene dimonomer. 
calculates gamma source strengths for any decay time desired. A total fuel burnup of $30 \mathrm{GWd} / \mathrm{MgU}$ over a period of $3 \mathrm{yr}$ was assumed along with a fuel enrichment of $3.0 \%$. About $0.5 \%$ of the heavy elements were assumed lost to the HLW stream at reprocessing. The PW-9 waste contains only HLW (no intermediateor low-level wastes). The only waste core considered was borosilicate glass, which is the least dense of all cores being considered and thus offers the least amount of shielding to the matrix material. Given the same matrix material, doses from any other waste core would be lower.

The results of the gamma dose calculation are shown in Table B.3. Doses were calculated for several intervals of time to show how the dose accumulates as a function of the age of the waste. "The dose accumulated in each time interval is shown so that one can determine what the effect would be of postponing the waste packaging.

\section{ALPHA DOSES}

The same waste sources, marble materials, and matrix materials as used for the gamma dose calculation were used for this analysis. Alpha emitters in the wastes are heavy metals, mostly $U$ and Pu. Although these elements are only present in low concentrations, it was felt that an investigation of the alpha dose was still warranted.

Alpha particles interact readily with most materials and thus do not penetrate very far. For the substances considered in this study, the typical range of $5.0 \mathrm{MeV}$ alphas is $1 \times 10^{-3}$ to $1.5 \times 10^{-3} \mathrm{~cm}$. Thus, the alpha radiation affects only a thin matrix layer around each waste marble and is emitted from the outer layer of the marble. (Alphas emitted deep within the marble will be absorbed there.) These layers are sufficiently thin to permit the calculation of absorbed alpha dose to be performed assuming slab geometry.

The results of the calculation are shown in Table B.4. The heavy metals have long half-lives; therefore, the alpha production rate (and hence the dose rate) is essentially constant over the 1000-yr period being considered. 
TABLE B.3. Accumulated Gamma Dose as a Function of Time(a)

\begin{tabular}{|c|c|c|c|c|c|c|c|}
\hline $\begin{array}{l}\text { Waste } \\
\text { Source }\end{array}$ & $\begin{array}{l}\text { Matrix } \\
\text { Material }\end{array}$ & to $5 \mathrm{yr}$ & $\frac{\text { Gamma Dose }}{5 \text { to } 10 \mathrm{yr}}$ & $\frac{\text { ccumulated ir }}{10 \text { to } 50 \mathrm{yr}}$ & $\frac{\text { Specific Time }}{50 \text { to } 100 \mathrm{yr}}$ & $\frac{\text { Intervals, rads }}{100 \text { to } 1000 \mathrm{yr}}$ & $\overline{c t a l}$ \\
\hline $\mathrm{PW}-9$ & EPDM Rubber & $3.6 \times 10^{10}$ & $2.3 \times 10^{10}$ & $6.5 \times 10^{10}$ & $2.8 \times 10^{10}$ & $2.96 \times 10^{10}$ & $1.8 \times 10^{11}$ \\
\hline $\mathrm{PW}-9$ & $90 \% \mathrm{~Pb}-10 \% \mathrm{Sn}$ & $9.7 \times 10^{9}$ & $6.2 \times 10^{9}$ & $1.8 \times 10^{10}$ & $7.4 \times 10^{9}$ & $8.3 \times 10^{9}$ & $4.9 \times 10^{10}$ \\
\hline SRL & EPDM Rubber & (b) & $1.2 \times 10^{9}$ & $5.4 \times 10^{9}$ & $1.8 \times 10^{9}$ & $1.2 \times 10^{9}$ & $9.6 \times 10^{9}$ \\
\hline SRL & $90 \% \mathrm{~Pb}-10 \% \mathrm{Sn}$ & -(b) & $1.2 \times 10^{8}$ & $1.2 \times 10^{8}$ & $3.5 \times 10^{8}$ & $2.9 \times 10^{8}$ & $1.9 \times 10^{9}$ \\
\hline
\end{tabular}

(a) Assumed packing fraction: 52 vol\% waste cores; 48 vol\% matrix. Waste core composition: 30 wt\% waste oxides; 70 wt\% frit. 1-cm diameter waste cores.

(b) Savannah River Laboratory (SRL) waste was considered to be at least 5 yr old. 
TABLE 8.4. Alpha Doses and Dose Rates (a)

\begin{tabular}{lllll}
$\begin{array}{l}\text { Waste } \\
\text { Source }\end{array}$ & \multicolumn{1}{c}{$\begin{array}{c}\text { Matrix } \\
\text { Material }\end{array}$} & & $\begin{array}{c}\text { Dose rate, } \\
\text { rad/yr }\end{array}$ & $\begin{array}{c}\text { 1000-yr } \\
\text { Cumulative } \\
\text { Dose, rads }\end{array}$ \\
PW-9 & EPDM Rubber & & $2.1 \times 10^{4}$ & $2.1 \times 10^{7}$ \\
PW-9 & $90 \%$ Pb-10\% Sn & $2.8 \times 10^{3}$ & $2.8 \times 10^{6}$ \\
SRL & EPDM Rubber & $7.4 \times 10^{2}$ & $7.4 \times 10^{5}$ \\
SRL & $90 \%$ Pb-10\% Sn & $1.0 \times 10^{2}$ & $1.0 \times 10^{5}$
\end{tabular}

(a) Assumptions identical to those assumed for gamma doses given in Table B.3.

APPLICATION OF RESULTS TO OTHER CONFIGURATIONS

An examination of Tables B.3 and B.4 shows that the alpha dose to the matrix, even in the thin layer around each waste marble, is negligible compared to the gamma dose. For this reason the following discussion has been confined to gamma results.

Other Matrix Materials

The two matrix materials analyzed in this study span the range of densities of all materials to be considered. Dose to other matrix materials for a given waste source will fall between the doses to these two materials in order of density. A rough approximation to the behavior of the dose rate versus matrix density curve is a straight line on a semilog plot (Figure B.1); that is, dose $\propto e^{- \text {constant } x \text { density. }}$

Other Waste Core Materials

The borosilicate glass analyzed in this study is the least dense of all waste core materials considered. Thus, doses that would result from the use of other waste core materials would be lower due to their higher densities. The variation of dose versus waste core density was not determined in any detail, but it may be noted that the waste core densities do not vary nearly as much as the matrix densities. As a result, the doses from using different waste core materials should not be very different from the calculated dose. 


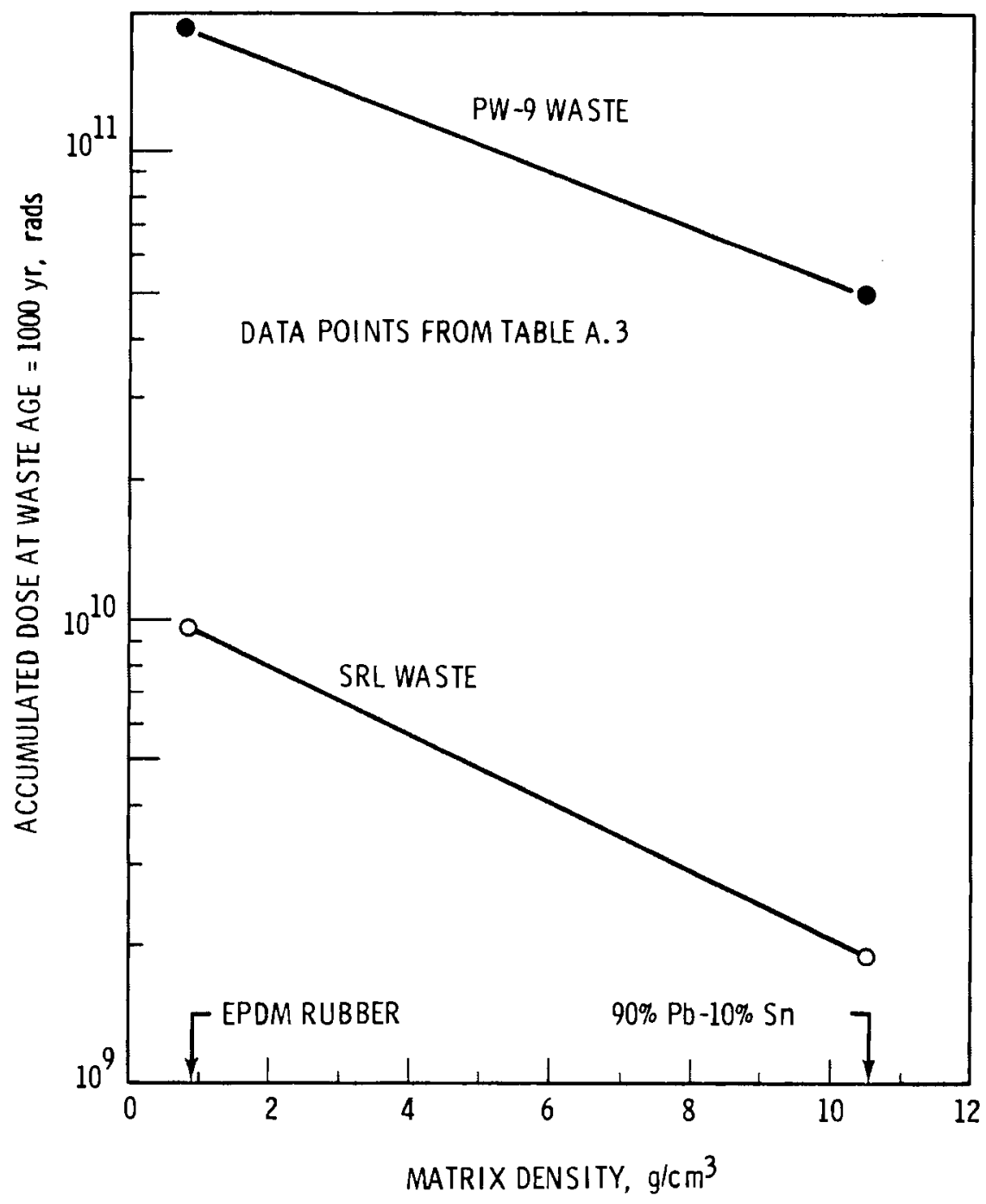

FIGURE B.1. Gamma Dose-to-Matrix as a Function of Matrix Density

\section{Different Packing Fractions}

For this analysis a simple cubic lattice was used as a sphere packing model. This lattice has a packing fraction of $52 \%$ sphere and $48 \%$ matrix. Other lattice arrangements are possible and the use of marbles of several different sizes would also change the packing fraction. In any case, the dose to the matrix should vary in proportion to the packing fraction. This assumption may break down at very low or very high packing fractions but should be valid for any realistic situation. In sum, dose a packing fraction. 
Different Waste Loadings

For this study each waste marble was assumed to be $30 \%$ waste and $70 \%$ glass frit. If the marble contained more or less waste, the dose to the matrix would be proportionally higher or lower. In sum dose $\propto$ waste loading.

Different Marble Sizes

This study assumed a marble diameter of $1 \mathrm{~cm}$ with all marbles being the same size. Using marbles of a different size (but still all the same) will have little effect on the matrix doses since the packing fraction for a regular lattice is not a function of sphere size. If various sizes of marbles are used, however, the packing fraction may change. The effect of this on the dose was discussed above. In sum, dose $\propto$ unaffected by marble size.

Different Ages of Waste

Since the source of the dose to the matrix is radioactive decay, the source strength diminishes with time. After $1000 \mathrm{yr}$ of exposure the dose per year is several orders of magnitude lower than at the start. Table B.5 shows the dose rates as a function of time for the two waste types and the two matrix materials considered in this study. The information in Table B. 3 was derived from Table B.5 by integrating over each time interval to find the accumulated dose.

\section{REFERENCES}

Be11, M. J. 1973. ORIGEN - The ORNL Isotope Generation and Depletion Code. ORNL-4628, Oak Ridge National Laboratory, Oak Ridge, Tennessee.

Lahti, G. P. 1967. QADHD Point-Kernal Radiation Shielding Computer Code to Evaluate Propellant Heating and Dose to Crew During Engine Operation. NASA-TM-X-1397, NASA, Lewis Research Center, Cleveland, Ohio.

Landon, E. F., compiler. 1980. Preliminary Technical Data Summary No. 3 for the Defense Waste Processing Facility. DPSTD-77-13-3, Savannah River Laboratory, Aiken, South Carolina.

Malenfant, R. E. 1967. QAD: A Series of Point-Kernal General-Purpose ShieldPrograms. LA-3573, Los Alamos Scientific Laboratory, Los Alamos, New Mexico.

Ross, W. A., et a1. 1978. Annual Report on the Characterization of High-Level Waste Glasses. PNL-2625, Pacific Northwest Laboratory, Richland, Washington. 

TABLE B.5. Gamma Dose Rate to Matrix Material as a Function
of Waste Age $(a)$

\begin{tabular}{|c|c|c|c|c|c|c|c|}
\hline \multirow{2}{*}{$\begin{array}{l}\text { Waste } \\
\text { Source }\end{array}$} & \multirow{2}{*}{$\begin{array}{c}\text { Matrix } \\
\text { Material }\end{array}$} & \multicolumn{6}{|c|}{ Dose Rate by waste Age, rads/yr } \\
\hline & & $2 \mathrm{yr}$ & $5 \mathrm{yr}$ & $10 \mathrm{yr}$ & $50 \mathrm{yr}$ & $100 \mathrm{yr}$ & $1000 \mathrm{yr}$ \\
\hline PW-9 & EPDM Rubber & $1.7 \times 10^{10}$ & $7.7 \times 10^{9}$ & $2.6 \times 10^{9}$ & $9.6 \times 10^{8}$ & $2.9 \times 10^{8}$ & $7.3 \times 10^{4}$ \\
\hline PW-9 & $90 \% \mathrm{~Pb}-10 \% \mathrm{Sn}$ & $4.7 \times 10^{9}$ & $2.1 \times 10^{9}$ & $6.8 \times 10^{8}$ & $2.6 \times 10^{8}$ & 7.7 & 1.9 \\
\hline SRL & EPDM Rut & -1 & $2.9 \times 10^{8}$ & $2.0 \times 10^{8}$ & $6.6 \times 10^{7}$ & $1.6 \times 10^{7}$ & $3.8 \times 10^{2}$ \\
\hline SRL & $90 \% \mathrm{~Pb}-10 \% \mathrm{Sn}$ & (b) & $6.7 \times 10^{7}$ & $4.7 \times 10^{7}$ & $1.2 \times 10^{7}$ & $3.7 \times 10^{6}$ & $9.3 \times 10^{1}$ \\
\hline
\end{tabular}

(a) See Table B.3 for assumptions.

(b) Savannah River Laboratory (SRL) waste is assumed to be at least 5 yr old. 


\section{DISTRIBUTION}

No. of

Copies

OFFSITE

A. A. Churm
DOE Chicago Patent Group
9800 South Cass Avenue
Argonne, IL 60439
T. C. Chee
DOE Office of Nuclear Waste
Management
NE-320, GTN
Washington, DC 20545
C. R. Cooley
DOE Office of Nuclear Waste
Management

NE-330, GTN

Washington, DC 20545

G. H. Daly

DOE Office of Nuclear Waste Management

NE-320, GTN

Washington, DC 20545

J. E. Dieckhoner

DOE Office of Nuclear Waste Management

NE-320, GTN

Washington, DC 20545

C. H. George

DOE Office of Nuclear Waste Management

NE-330, GTN

Washington, DC 20545
No. of

Copies

C. A. Heath

DOE Office of Nuclear Waste Management

NE-330, GTN

Washington, DC 20545

M. L. Lawrence

DOE Office of Nuclear Waste Management

NE-340, GTN

Washington, DC 20545

D. J. McGoff

DOE Office of Nuclear Waste Management

NE-320, GTN

Washington, DC 20545

S. Meyers/R. Romatowsk i

DOE Office of Nuclear Waste Management

NE-30, GTN

Washington, DC 20545

G. Oertel

DOE Office of Nuclear Waste Management

NE-320, GTN

Washington, DC 20545

A. F. Perge

DOE Office of Nuclear Waste Management

NE-30, GTN

Washington, DC 20545

R. W. Ramsey, Jr.

DOE Office of Nuclear Waste

Management

NE-30.1, GTN

Washington, DC 20545 
No. of

Copies

D. L. Vieth

DOE Office of Nuclear Waste

Management

NE-350, GTN

Washington, DC 20545

R. D. Walton

DOE Office of Nuclear Waste

Management

NE-320, GTN

Washington, DC 20545

W. G. Belter

DOE Division of Biomedical and Environmental Research

Earth Sciences Branch

Washington, DC 20545

W. A. Brobst

DOE Division of Environmental

Control Technology

Washington, DC 20545

W. E. Mott

DOE Division of Environmental

Control Technology

Washington, DC 20545

R. B. Chitwood

DOE Division of Nuclear Power Development

Washington, DC 20545

A. L. Taboas

DOE Albuquerque Operations Office

P.0. Box 5400

Albuquerque, NM 87185

S. A. Mann

DOE Chicago Operations and

Region Office

Argonne, IL 60439

J. Neff

DOE Columbus Program Office

505 King Avenue

Columbus, $\mathrm{OH} \quad 43201$
No. of

Copies

K. A. Carlson

DOE Idaho Operations Office

550 2nd Street

Idaho Falls, ID 83401

S. W. Ahrends

DOE Oak Ridge Operations Office

P.0. Box E

Oak Ridge, TN 37830

2 Central Research Library

Document Reference Section

Oak Ridge National Laboratory (DOE)

Oak Ridge, TN 37830

S. G. Harbinson

DOE San Francisco Operations

1333 Broadway

0akland, CA 94612

E. S. Goldberg

DOE Savannah River Operations Office

P.0. Box A

Aiken, SC 29801

27 DOE Technical Information Center

J. A. Buckham

Allied-General Nuclear Services

P.0. Box 847

Barnwell, SC 29812

J. W. Bartlett

The Analytical Sciences Corp.

6 Jacob Way

Reading, MA 01867

M. J. Steindler/L. E. Trevorrow

Argonne National Laboratory

9700 South Cass Avenue

Argonne, IL 60439

R. G. Post

College of Engineering

University of Arizona

Tucson, AZ 85721 
No. of

Copies

J. M. Batch

Battelle Memorial Institute 505 King Avenue

Columbus, $\mathrm{OH} 43201$

A. Brandstetter

Battelle Memorial Institute

Office of Nuclear Waste

Isolation

505 King Avenue

Columbus, $\mathrm{OH} 43201$

Beverly Rawles

Battelle Memorial Institute

Office of Nuclear Waste

Isolation

$505 \mathrm{King}$ Avenue

Columbus, $\mathrm{OH} 43201$

Research Library

Battelle Memorial Institute

$505 \mathrm{King}$ Avenue

Columbus, $\mathrm{OH} 43201$

2 Brookhaven National Laboratory

Reference Section

Information Division

Upton, Long Island, NY 11973

J. R. Potter

Chem-Nuclear Systems, Inc.

P.0. Box 1866

Bellevue, WA 98009

Combustion Division

Combustion Engineering, Inc.

windsor, CT 06095

M. D. McCormack

EGaG Idaho

P.0. Box 1625

Idaho Falls, ID 83415

L. Henning

Electric Power Research

Institute

3412 Hillview Avenue

P.0. Box 10412

Palo Alto, CA 94304
No. of

Copies

R. Williams

Electric Power Research Institute

3412 Hillview Avenue

P.0. Box 10412

Palo Alto, CA 94304

J. L. Larocca, Chairman

Engineering Research and Development Authority

Empire State Plaza

Albany, NY 12223

J. R. Berreth

Exxon Nuclear Idaho

P.0. Box 2800

Idaho Falls, ID 83401

Exxon Nuclear Idaho

(File Copy)

P.0. Box 2800

Idaho Falls, ID 83401

L. L. Hench

Dept. of Materials Science and Engineering

University of Florida

Gainesville, FL 32611

R. G. Barnes

General Electric Company

175 Curtner Avenue

(M/C 160)

San Jose, CA 95125

L. H. Brooks

Gulf Energy and Environmental Systems

P.0. Box 81608

San Diego, CA 92138

J. Campbel 1

Lawrence Livermore Laboratory

P.0. Box 808

Livermore, CA 94550 
No. of

Copies

B. Adams

Corning Glass Works

Technical Staffs Division

Corning, NY 14830

Los Alamos Scientific Laboratory P.0. Box 1663

Los Alamos, NM 87544

R. Roy

202 Materials Research

Laboratory

University Park, PA 16802

C. J. Kershner

Monsanto Research Corporation

Mound Laboratory

P.0. Box 32

Miamisburg, $\mathrm{OH} 45342$

John Pomeroy

Technical Secretary

National Academy of Sciences

Committee of Radioactive Waste

Management

National Research Council

2101 Constitution Avenue

Washington, DC 20418

S. Farber

New England Power Company

280 Melrose Street

Providence, RI 02901

Rod Ewing

University of New Mexico

Albuquerque, NM 87131

S. E. Logan

University of New Mexico

Albuquerque, NM 87131

H. Palmour, III

2140 Burlington Engineering Laboratories

North Carolina State University

Raleigh, NC 27607
No. of

Copies

G. J. McCarthy

Department of Chemistry

North Dakota State University

Fargo, ND 58102

J. P. Duckworth

Plant Manager

Nuclear Fuels Services, Inc.

P.0. Box 124

West Valley, NY 14171

R. E. Blanco

Oak Ridge National Laboratory

P.0. Box $Y$

Oak Ridge, TN 37830

E. H. Kobisk

Oak Ridge National Laboratory

P.0. Box Y

Oak Ridge, TN 37830

W. J. Lackey

Oak Ridge National Laboratory

P.0. Box $Y$

Oak Ridge, TN 37830

T. H. Row

Oak Ridge National Laboratory

P.0. Box $X$

Oak Ridge, TN 37830

F. K. Pittman

3508 Sagecrest Terrace

Ft. Worth, TX 76109

W. S. Bennett

Rockwel 1 International

Rocky Flats Plant

P.0. Box 464

Golden, C0 80401

A. M. Martin

Rockwell International

8900 DeSoto Avenue

Canoga Park, CA 91304 
No. of

Copies

J. K. Johnstone

Sandia Laboratories

Albuquerque, NM 87185

Professor Guna Salvaduray

Materials Engineering

San Jose State University

San Jose, CA 95192

R. G. Garvin

E. I. du Pont de Nemours Co.

Savannah River Laboratory

Aiken, SC 29801

J. A. Kelley

E. I. du Pont de Nemours Co.

Savannah River Laboratory

Aiken, SC 29801

M. S. Plodinec

E. I. du Pont de Nemours Co.

Savannah River Laboratory

Aiken, SC 29801

Environmental Protection Agency

Technological Assessment

Division (AW-559)

Office of Radiation Programs

U.S. Environmental Protection Agency

Washington, DC 20460

R. A. Beall

U.S. Department of Interior

Bureau of Mines

Albany Research Center

$1450 \mathrm{~W}$. Queen Avenue

Albany, OR 87321

D. B. Stewart

U.S. Department of Interior

959 National Center

Geological Survey

Reston, VA 22092
No. of

Copies

R. E. Cunningham

Office of Nuclear Safety Materials and Safeguards

Room 562

U.S. Nuclear Regulatory Commission 7915 Eastern Avenue

Silver Springs, MD 20910

J. B. Martin

Division of Waste Management

U.S. Nuclear Regulatory Commission

Washington, DC 20555

W. Tope

Westinghouse Electric

Corporation

Penn Center, Building 2

Box 355

Pittsburgh, PA 15230

ONSITE

4 DOE Richland Operations Office

H. E. Ransom

J. J. Schreiber (2)

M. W. Shupe

13 Rockwell Hanford Operations

H. Babad

L. C. Brown

R. A. Deju

R. J. Gimera

D. R. Gustavson

E. J. Kosiancic

C. M. Manry

M. J. Kupfer 
I. E. Reep

D. D. Wodrich

W. W. Schulz

M. J. Smith

File Copy

UNC United Nuclear Industries

F. H. Bouse, Document Control

Westinghouse Hanford Company

A. G. Blasewitz

52 Pacific Northwest Laboratory

G. S. Allison

H. T. Blair

D. W. Brite

L. R. Bunnel

T. D. Chikalla

E. L. Courtright

S. D. Dahlgren

R. L. Dillon

D. A. Dingee

S. K. Edler

R. P. Elmore
H. T. Fullam

W. J. Gray

W. E. Gurwell (10)

C. R. Hann

P. E. Hart

A. B. Johnson, Jr.

R. S. Kemper

R. 0 . Lokken

W. C. Morgan

R. D. Nelson

R. G. Nelson

J. F. Nesbitt

A. M. Nolan

K. H. Oma

S. G. Pitman

M. W. Poquette

W. A. Ross

J. M. Rusin

J. W. Shade

W. E. Skeins

S. C. Slate

R. L. Treat

R. P. Turcotte

J. W. Wald

R. E. Westerman

Technical Information (5)

Publishing Coordination YO(2) 